\title{
Development and origin of the microgranular structure in Latosols of the Brazilian Central \\ Plateau: significance of texture, mineralogy, and biological activity
}

Adriana Reatto ${ }^{(1,2)}$, Ary Bruand ${ }^{(2)^{*}}$, Eder de Souza Martins ${ }^{(1)}$, Fabrice Muller ${ }^{(2)}$, Euzebio Medrado da Silva $^{(1)}$, Osmar Abílio de Carvalho Jr ${ }^{(3)}$, Michel Brossard ${ }^{(4)}$, Guy Richard ${ }^{(5)}$

${ }^{(1)}$ Empresa Brasileira de Pesquisa Agropecuária (Embrapa Cerrados), BR 020, km 18, 73310-970, Planaltina, Distrito Federal, Brazil. E-mail: reatto@cpac.embrapa.br, eder@cpac.embrapa.br, euzebio@cpac.embrapa.br. ${ }^{(2)}$ Université d'Orléans, CNRS/INSU, Université de Tours, Institut des Sciences de la Terre d'Orléans (ISTO), 1A rue de la Férollerie, 45071 Orléans Cedex 2, France. Email: adriana.reatto@univ-orleans.fr, Ary.Bruand@univ-orleans.fr, Fabrice.Muller@univ-orleans.fr. ${ }^{(3)}$ Departamento de Geografia - Universidade de Brasília (UnB), 70910-000, Brasília, Brazil. E-mail: osmarjr@unb.br. ${ }^{(4)}$ Institut de Recherche pour le Développement (IRD), Unité Valpédo, BP 64501, 34394 Montpellier Cedex 5, France. E-mail: Michel.Brossard@mpl.ird.fr. ${ }^{(5)}$ INRA Orléans, Unité de Science du Sol, Ardon, BP 20619, 45166 Olivet Cedex, France. E-mail: Guy.Richard@orleans.inra.fr

\footnotetext{
* Corresponding author: Ary.Bruand@univ-orleans.fr
}

\begin{abstract}
Brazilian Latosols are characterized by low activity clay, little horizon differentiation, a weak macrostructure and a strong microgranular structure. The development of the latter that was reported as being possibly related to the fine material mineralogy, location in the landscape, parental material and biological activity is still under discussion. The aim of this study is to discuss the origin of the microgranular structure of Latosols located in the Brazilian Central Plateau. Ten Latosols (L) developed in different parent materials were selected along an approximately 350-km long regional toposequence across the South American Surface (SAS) (L1 to L4) and Velhas Surface (VS) (L5 to L10). The structure of the Latosols was studied in the field and samples of the diagnostic Bw horizons were
\end{abstract}


collected for laboratory analyses. Basic soil characterization was performed on the <2-mm material according to the Brazilian standard procedures. The $\mathrm{SiO}_{2}, \mathrm{AL}_{2} \mathrm{O}_{3}, \mathrm{Fe}_{2} \mathrm{O}_{3}$ and $\mathrm{TiO}_{2}$ content was determined after dissolution with $1: 1 \mathrm{H}_{2} \mathrm{SO}_{4}$. The microstructure was studied in optical microscopy and electron scanning electron microscopy in thin sections. The results showed a varying compound strong microgranular structure and weak to moderate medium sub-angular blocky structure independently of the landscape position as well as the parental material, except for the Latosol developed on a quartzite. The Latosols were classified as gibbsitic-sexquioxic, kaolinitic non-sesquioxid, or kaolinitic-sesquioxid Latosols but there was no relationship between their composition and the development of the microgranular structure in the $\mathrm{Bw}$ horizon. The analyses showed indeed several types of microgranular structure with different proportions but without any relationship with their texture and mineralogy. Actually, the types of microgranular structure appeared to be mainly related to soil bioturbation by termites and eventually secondarily by ants. Thus, the weak macrostructure and strong microgranular structure of the Latosols studied, the little vertical differentiation of the horizons, and the lack of a clear relationship between their landscape position and parent material characteristics would result from long-term biotic action with high probability.

Keywords: Oxisol; Porosity; Termite; Soil structure; Brazil; Micromorphology; Microstructure

\section{Introduction}

Soil structure corresponds to the organization of the primary soil particles into secondary units that are called aggregates or peds (Allaby and Allaby, 2003). These secondary units are defined on the basis of their shape, size, and grade. They can be easily 
affected by the climate, biological activity, and soil management. In Brazil, Latosols occupy about $2,835,000 \mathrm{~km}^{2}$ and $1 / 3$ of the national territory (Ker, 1998). They are characterized by little differentiation of their horizons, low activity clay, a weak macrostructure, and a strong submillimetric granular structure (Embrapa, 1999). In the Brazilian Soil Taxonomy (Embrapa, 1999), Latosols are defined by the presence of a diagnostic horizon Bw between the surface and $200 \mathrm{~cm}$ depth. This horizon is characterized by 1:1 clay minerals, variable amount of iron content, and $\mathrm{SiO}_{2}$ and $\mathrm{Al}_{2} \mathrm{O}_{3}$ removable by $\mathrm{H}_{2} \mathrm{SO}_{4}$, such as $\mathrm{SiO}_{2} / \mathrm{Al}_{2} \mathrm{O}_{3} \leq 2.2$. Most Latosols are Oxisols according to the Soil Taxonomy (Soil Survey Staff, 2006) or Ferralsols in the World Reference Base (IUSS Working Group WRB, 2006). The development of the microgranular structure was discussed in numerous studies based on the clay mineralogy, location in the landscape, parental material, and biological activity. Lima (1988) stated that the development of the microgranular structure in the Bw horizon would increase with the hematite content in the clay fraction. Vidal-Torrado and Lepsch (1993) found a microgranular structure more developed on the upper slope than on the lower slope where the microgranular structure was weak or even absent in combination with a massive argillic horizon. Bennema et al. (1970) studied oxic and argillic horizons and showed an increase in the microgranular structure development with the clay content regardless clay mineralogy variation. The independency of the microgranular structure from the clay mineralogy was also observed by Gomes et al. (2004). On the other hand several authors showed that the microgranular structure was less developed in kaolinitic Latosols than in gibbsitic Latosols (Ferreira et al., 1999; Viana et al., 2004; Schaefer et al., 2004). Schaefer (2001) studied a set of $\mathrm{Bw}$ horizons with $\mathrm{SiO}_{2}, \mathrm{Al}_{2} \mathrm{O}_{3}$ and $\mathrm{Fe}_{2} \mathrm{O}_{3}$ removable by $\mathrm{H}_{2} \mathrm{SO}_{4}$ such as $0.28<\mathrm{SiO}_{2} / \mathrm{Al}_{2} \mathrm{O}_{3}<1.17$ and $80<\mathrm{Fe}_{2} \mathrm{O}_{3}<170 \mathrm{~g} \mathrm{~kg}^{-1}$. They recorded a uniform microgranular structure with different degrees of roundness in spite of the great variability of parent material and mineralogy. The influence of the biological activity on microgranular 
structure was also discussed by (Eschenbrenner, 1986). Schaefer (2001) and Schaefer et al. (2002) said that the quartz grains in the centre of microaggregates were smaller than in the surroundings which indicates the biological origin including grain size segregation by termites and other soil animals. Based in this, Schaefer (2001) concluded that the microgranular structure of Brazilian Latosols would result from long-term biological activity. Balbino et al. (2001, 2002) and Volland-Tuduri (2005b) also studied the microgranular structure of this soil type and proposed that it might result from termite and ant activity. Thus the origin of the microgranular structure of Brazilian Latosols is still under discussion. The aim of this study is to analyze the characteristics of the microstructure development in Latosols that originated from different parental materials and are located on the two main geomorphic surfaces of the Central Plateau. The study also shows that the microstructure would be related to bioturbation by termites mainly.

\section{Material and Methods}

\subsection{Site conditions}

The Brazilian Central Plateau covers about $10 \%$ of the continuous Cerrados Biome and represents $176,000 \mathrm{~km}^{2}$ (Silva et al., 2005). Latosols occupy about $40 \%$ of its surface area (Fig. 1). The Central Plateau corresponds to two main geomorphic surfaces, the South American Surface (SAS) and Velhas Surface (VS) (King, 1956; Lepsch and Buol, 1988; Motta et al., 2002; Marques et al., 2004). The SAS corresponds to a Brazilian landscape that begins as a vast peneplain produced by denudation between the lower Cretaceous and middle Tertiary. At this time, very humid climatic conditions were favorable for a deep weathering of rocks. The continent was uplifted afterwards and polycyclic stream incision carved valleys into the surface, transforming it into a dissected upland. Braum (1971) reported the tablelands (chapadas) 900 to 1200-m high of Central Brazil as corresponding to remnants of the SAS. 
They appear as smoothly convex plane portions that terminates either as an abruptly escarpment or as a kind of a stepwise border on the sides of the plateau. The VS that initiates at the dissection of the SAS and is characterized by moderate slope, convex forms, and covers smaller extensions than the SAS. According to the Köppen (1931) classification, the most representative climate of the Central Plateau is Megatermic or Humid Tropical (Aw) with the subtype savanna. It is characterized by a dry winter (medium temperature of the coldest month $>18^{\circ} \mathrm{C}$ ) and maximum rains in summer. The mean annual rainfall ranges from 1,500 to 2,000 mm, with the highest rainfall in January and the smallest in June, July and August $\left(<50 \mathrm{~mm} \mathrm{month}^{-1}\right)$. The relative humidity of the air is about $75 \%$ between January and April and about 30\% during the dry winter (Assad et al., 1993).

\subsection{Soil selection and characterization}

According to Reatto et al. (2000), ten Latosols (L) developed in different parent materials were selected along an approximately $350-\mathrm{km}$ long regional toposequence across the SAS (L1 to L4) and VS (L5 to L10) (Fig. 2 and Table 1). Basic characteristics and hydraulic properties of these Latosols can be found in Reatto et al. (2007) and data on the clay mineralogy of their Bw horizons in Reatto et al. (2008). The Latosols L7 and L8 were studied by Volland et al. (2004 and 2005a) and are similar to those studied by Balbino et al. (2001, 2002 and 2004). The Latosols L5 and L6 were located on the upper VS, L7 and L8 on the intermediate VS, and L9 and L10 on the lower VS. Soils were described according to the field manual of Lemos and Santos (1996) and the Brazilian Soil Taxonomy (Embrapa, 1999). About 2-m deep soil pits were dug and the top horizon (A), transitional horizons (AB and $\mathrm{BA})$, and diagnostic horizon $(\mathrm{Bw})$ were described. Disturbed samples were collected in every horizon. Basic soil characterization was performed on the air-dried $<2-\mathrm{mm}$ material according to the Brazilian standard procedures as described by Embrapa (1997) which in general follow 
the international procedures (Klute, 1986; Page et al., 1982). The particle size distribution was determined using the pipette method after dispersion with $\mathrm{NaOH} 1 \mathrm{~N}$. The particle density was determined by using $95 \%$ hydrated alcohol with $20 \mathrm{~g}$ of air-dried soil material in a 50-ml pycnometer. The bulk density was calculated using the oven-dried mass of soil material contained in cylinders $100-\mathrm{cm}^{3}$ in volume $(\varnothing=5.1 \mathrm{~cm}, \mathrm{~h}=5 \mathrm{~cm})$. The soil $\mathrm{pH}$ was measured in distilled water and $1 \mathrm{~N} \mathrm{KCl}$ using 1:1 mass soil to solution ratio. The cation exchange capacity (CEC) was computed as being the sum of the electric charges of $\mathrm{Ca}^{2+}, \mathrm{Mg}^{2+}$, and $\mathrm{Al}^{3+}$ extracted with $1 \mathrm{~N} \mathrm{KCl}$, of $\mathrm{K}^{+}$and $\mathrm{Na}^{+}$extracted with $0,05 \mathrm{~N} \mathrm{HCl}$, and of $\mathrm{H}^{+}$and $\mathrm{Al}^{3+}$ extracted with a tampon solution of $\mathrm{Ca}\left(\mathrm{CH}_{3} \mathrm{COO}\right)_{2}$ and $\mathrm{CH}_{3} \mathrm{COOH}$ at $\mathrm{pH}$ 7.0. The organic carbon content was analyzed by wet oxidation with $0.4 \mathrm{~N} \mathrm{~K}_{2} \mathrm{Cr}_{2} \mathrm{O}_{7}$.

The $\mathrm{SiO}_{2}, \mathrm{Al}_{2} \mathrm{O}_{3}, \mathrm{Fe}_{2} \mathrm{O}_{3}$ and $\mathrm{TiO}_{2}$ content was estimated after dissolution in 1:1 $\mathrm{H}_{2} \mathrm{SO}_{4}$ (Vettori, 1959; Camargo et al., 1986; Embrapa, 1997; Marques, 2000). The $\mathrm{SiO}_{2}\left(S_{\mathrm{SiO}_{2}}\right)$ and $\mathrm{Al}_{2} \mathrm{O}_{3}\left(S_{\mathrm{Al}_{2} \mathrm{O}_{3}}\right)$ contents extracted with sulfuric acid were used to compute the $K i$ ratio and $K r$ ratio plus $\mathrm{Fe}_{2} \mathrm{O}_{3}$ in according (Resende and Santana, 1988) defined as follows:

$$
\begin{gathered}
K i=\frac{\frac{\left(S_{\mathrm{SiO}_{2}}\right)}{\frac{60}{\left(S_{\mathrm{Al}_{2} \mathrm{O}_{3}}\right)}}=1.7 \times \frac{\left(S_{\mathrm{SiO}_{2}}\right)}{(02}}{\left(S_{\mathrm{Al}_{2} \mathrm{O}_{3}}\right)} \\
K r=\frac{\frac{\left(S_{\mathrm{SiO}_{2}}\right)}{60}}{\frac{\left(S_{\mathrm{Al}_{2} \mathrm{O}_{3}}\right)}{102}+\frac{\left(S_{\mathrm{Fe}_{2} \mathrm{O}_{3}}\right)}{160}}=1.7 \times\left(S_{\mathrm{SiO}_{2}}\right) /\left[\left(S_{\mathrm{Al}_{2} \mathrm{O}_{3}}\right)+0.6375 \times\left(S_{\mathrm{Fe}_{2} \mathrm{O}_{3}}\right)\right]
\end{gathered}
$$

The kaolinite $(K t)$ and gibbsite $(G b)$ contents were determined as follows (Resende et al., 1987; Bruand and Prost, 1988):

$$
K t=S_{\mathrm{SiO}_{2}} / K t_{\mathrm{SiO}_{2}}
$$




$$
G b=\left\lfloor\left(S_{\mathrm{Al}_{2} \mathrm{O}_{3}}-K t \times\left(K t_{\mathrm{Al}_{2} \mathrm{O}_{3}} / 1000\right)\right) / G b_{\mathrm{Al}_{2} \mathrm{O}_{3}}\right\rfloor
$$

where $K t$ is the kaolinite content (in $\mathrm{g} \mathrm{kg}^{-1}$ ) of the sample, $K t_{\mathrm{SiO}_{2}}$ the $\mathrm{SiO}_{2}$ content of kaolinite and equaled to 465 in $\mathrm{g} \mathrm{kg}^{-1}, \mathrm{Kt}_{\mathrm{Al}_{2} \mathrm{O}_{3}}$ the $\mathrm{Al}_{2} \mathrm{O}_{3}$ content of kaolinite and equaled to $395 \mathrm{in} \mathrm{g} \mathrm{kg}^{-}$ ${ }^{1}, \mathrm{~Gb}_{\mathrm{Al}_{2} \mathrm{O}_{3}}$ the $\mathrm{Al}_{2} \mathrm{O}_{3}$ content of gibbsite and equaled to 654 in $\mathrm{g} \mathrm{kg}^{-1}$. Equations (3) and (4) assumed kaolinite and gibbsite without any substitution.

The goethite $(\mathrm{Gt})$ and hematite $(\mathrm{Hm})$ contents were computed by combining the two equations as follows:

$$
\begin{aligned}
& S_{\mathrm{Fe}_{2} \mathrm{O}_{3}}=0.8989 \times G t+H m \\
& H m /(H m+G t)=(R I-3.50) / 8.33
\end{aligned}
$$

where $S_{\mathrm{Fe}_{2} \mathrm{O}_{3}}$ is the $\mathrm{Fe}_{2} \mathrm{O}_{3}$ content (in $\mathrm{g} \mathrm{kg}^{-1}$ ) of the sample recorded with $\mathrm{H}_{2} \mathrm{SO}_{4}$ extraction, 0.8989 the specific proportion of $\mathrm{Fe}_{2} \mathrm{O}_{3}$ in a goethite (goethite and hematite was assumed as being no Al-substituted), RI is the red index according (Santana, 1984; Kampf et al., 1988) and equaled to:

$$
R I=(M+C / V)
$$

with $M$ a parameter related to the hue, $C$ the chroma and $V$ the value.

Undisturbed samples of the Bw horizon were also collected in triplicate by using cylinders of $100-\mathrm{cm}^{3}$ in volume. They were impregnated with a polyester resin that was diluted with styrene monomer and left 4 weeks to ensure complete polymerization. Vertical thin sections $\left(4 \times 6 \mathrm{~cm}^{2}\right)$ were produced following the method of Fitzpatrick (1984) and examined under optical microscopy using a Zeiss polarizing microscope equipped with a digital camera. The pedological features of the $\mathrm{Bw}$ horizon were described using standard micromorphological techniques (Bullock et al., 1987; Stoops, 2003). Estimation of the proportion of surface area occupied by each type of microstructure was performed visually by using the frequency charts proposed by Fitzpatrick (1984). The thin sections were also studied 
in scanning electron microscopy (SEM, Cambridge 90B) using the emission of backscattered electrons (Bruand et al., 1996).

\section{Results}

\subsection{Field observations}

The Latosols studied showed a compound weak to moderate medium sub-angular blocky structure and strong fine to very-fine granular structure. Dense irregular sub-rounded volumes (DIRV) of soil with varying size and material similar to the surrounding soil were recorded in different proportions in the Latosols studied (Table 2). The DIRV were described as clay nodules in Reatto et al. (2007). The biological macrocrovoids were represented by fine channels 1 to 2-mm in diameter resulting from root activity and channels varying in their size and cavities several centimeters in diameters both related to termite or ant activity (Table 2). In L1, high content in DIRV $<10$-mm in size was recorded between 100 and $200 \mathrm{~cm}$ depth. Another characteristic of L1 was the high quartz grain content and iron nodules $<0.5 \mathrm{~mm}$ in size content in different depths. The biological macrovoids were concentrated within the upper 100-cm. In L2 and L3, the greatest DIRV content was detected between 30 and $70-\mathrm{cm}$ depth that differed much in size (from 5 to $50-\mathrm{mm}$ ). Biological macrovoids were very few in these two profiles. In L4, any DIRV was evidenced. This profile showed also distinct mottles (7.5YR 5/6) below 130-cm depth and fragments of weathered plinthite (5YR 5/4) below 160cm depth ( $\mathrm{Bw}_{2}$ horizon). Numerous DIRV from 5 to $50-\mathrm{mm}$ in size were recorded in L5 from the surface to $90-\mathrm{cm}$ depth. Only a few biological macrovoids were observed in these two profiles. In L6, L7 and L8, numerous biological macrovoids were recorded in the whole profile and high DIRV content with sizes varying from 5 to $50-\mathrm{mm}$ between 20 and $140-\mathrm{cm}$ depth. Finally, in L9 and L10 biological macrovoids were very few and DIRV were recorded between 15 to $110-\mathrm{cm}$ depth. 


\subsection{Physico-chemical properties}

The clay content of the $\mathrm{Bw}$ horizons ranged from 300 to $780 \mathrm{~g} \mathrm{~kg}^{-1}$ (Table 3). A large range of bulk density $(\mathrm{Db})$ was also recorded for the $\mathrm{Bw}$ horizons of these Latosols with $0.83 \leq \mathrm{Db} \leq 1.21 \mathrm{~g} \mathrm{~cm}^{-3}$. The $\mathrm{pH}_{\mathrm{w}}$ varied from 4.80 to 5.34 and the $\mathrm{pH}_{\mathrm{KCl}}$ from 4.00 to 6.20. The $\mathrm{pH}_{\mathrm{w}}$ and $\mathrm{pH}_{\mathrm{KCl}}$ of the $\mathrm{Bw}$ horizons was greater in the Latosols on the SAS $\left(5.20 \leq \mathrm{pH}_{\mathrm{w}} \leq 5.34\right.$ and $\left.5.73 \leq \mathrm{pH}_{\mathrm{KCl}} \leq 6.20\right)$ than in those of the Latosols located on the VS $\left(4.80 \leq \mathrm{pH}_{\mathrm{w}} \leq 5.20\right.$ and $\left.4.00 \leq \mathrm{pH}_{\mathrm{KCl}} \leq 5.50\right)$. The organic carbon content ranged from 0.01 to $0.62 \mathrm{~g} \mathrm{~kg}^{-1}$ and the cation exchange capacity (CEC) from 1.73 to $10.60 \mathrm{cmol}_{\mathrm{c}} \mathrm{kg}^{-1}$. On the SAS, the Bw horizons showed high levels of $\mathrm{Al}_{2} \mathrm{O}_{3}$ content, (average $S_{\mathrm{Al}_{2} \mathrm{O}_{3}}=577 \mathrm{~g} \mathrm{~kg}^{-1}$ ), and small $\mathrm{SiO}_{2}$ content, (average $S_{\mathrm{SiO}_{2}}=165 \mathrm{~g} \cdot \mathrm{kg}^{-1}$ ) (Table 3 ). On the opposite, on the VS the Bw horizons showed small $\mathrm{Al}_{2} \mathrm{O}_{3}$ content (average $S_{\mathrm{Al}_{2} \mathrm{O}_{3}}=468 \mathrm{~g} \mathrm{~kg}^{-1}$ ) and high $\mathrm{SiO}_{2}$ content, (average $S_{\mathrm{SiO}_{2}}=302 \mathrm{~g} \mathrm{~kg}^{-1}$ ). The $\mathrm{Fe}_{2} \mathrm{O}_{3}$ and $\mathrm{TiO}_{2}$ contents $\left(S_{\mathrm{Fe}_{2} \mathrm{O}_{3}}\right.$ and $S_{\mathrm{TiO}_{2}}$, respectively) were slightly greater in the Bw horizons on the SAS (average $S_{\mathrm{Fe}_{2} \mathrm{O}_{3}}=230 \mathrm{~g} \mathrm{~kg}^{-1}$, average $S_{\mathrm{TiO}_{2}}=28 \mathrm{~g} \mathrm{~kg}^{-1}$ ) than in those on the VS (average $S_{\mathrm{Fe}_{2} \mathrm{O}_{3}}=210 \mathrm{~g} \mathrm{~kg}^{-1}$, average $S_{\mathrm{TiO}_{2}}=19 \mathrm{~g}$ $\mathrm{kg}^{-1}$ ) (Table 3).

\subsection{Observations in microscopy}

The Bw horizons studied showed several types of microgranular structure according to their development and related inter-microaggregates voids. A strong microgranular structure with well developed microaggregates 50 to $200-\mu \mathrm{m}$ in size that are combined in a loose assemblage with 40 to $50 \%$ of the surface area large compound packing voids (type A) was recorded in all the Bw horizons (Fig. 3a and b; Fig. 4a) except in L4. The microaggregates showed a double-spaced-porphyric and open-porphyric coarse/fine related distribution in the 
groundmass (Stoops, 2003). A microgranular structure developed as well as in the type A with similar internal characteristics but with microaggregates combined in a close assemblage (type B) with 20 to $35 \%$ of the surface area corresponding to complex packing voids was also observed in all the Bw horizons but in smaller proportion than type A (Fig. 3c and d; Fig. 4b). Besides types A and B, a very weak microgranular structure with a compact assemblage of microaggregates and 10 to $30 \%$ of the surface area corresponding regular and star-shaped vughs, channels and planar voids (type C) was detected (Fig. 3e and f; Fig. 4c). Finally, a microstructure corresponding to the assemblage of partially clay coated quartz grains with small rounded microaggregates 10 to $30-\mu \mathrm{m}$ in size (type D) with simple to compound packing voids corresponding to 30 to $40 \%$ of the surface area was also visualized (Fig. $3 \mathrm{~g}$ and h; Fig. 4d).

Observations of the thin sections of the Bw horizons under optical microscopy showed around $95 \%$ of the surface area in L3 and L6 corresponded to type A (Table 4) with compound and complex packing voids in L3 and simple to compound packing voids in L6 (Stoops, 2003). In L2, the observations showed that type A was dominant (70\%) and associated with type $\mathrm{C}(30 \%)$. The other Bw horizons studied showed a varying proportion of the types A, B and C (Table 4, Figure 5), except for L4 where the microstructure corresponded to type $\mathrm{D}$ alone.

\section{Discussion}

\subsection{Mineralogical classification of the Latosols studied}

Latosols are classified as kaolinitic Latosols or gibbsitic Latosols according to the value of the $K i$ ratio in the diagnostic Bw horizon. They can be also classified as sexquioxid Latosols or not according to the value of the $K r$ ratio (Resende and Santana, 1988). The $K i$ ratio ranged from 0.3 to 1.4 and $K r$ ratio from 0.3 to 1.0 (Table 5). On the SAS, $0.3 \leq K i \leq 0.7$ 
and $0.3 \leq K r \leq 0.6$ when on the VS $0.7 \leq K i \leq 1.4$ and $0.6 \leq K r \leq 1.0$ for the Bw horizons studied. Hence, L1, L2, L3 and L4 located on the SAS and L10 on the VS were classified as gibbsitic-sexquioxidic Latosols, L5, L7, L8 and L9 on the VS as kaolinitic non-sesquioxidic Latosols and L6 on the VS as kaolinitic-sesquioxidic Latosol.

\subsection{Mineralogy of the diagnostic Bw horizons}

The results showed that the $K t$ content was smaller $\left(196 \leq K t \leq 412\right.$ in $\left.\mathrm{g} \mathrm{kg}^{-1}\right)$ in most Bw horizons of the Latosols located on the SAS than in those of the Latosols located on the VS $\left(399 \leq K t \leq 645\right.$ in $\mathrm{g} \mathrm{kg}^{-1}$ ) (Table 5). In contrast, the $G b$ content was higher $\left(442 \leq G b \leq 625\right.$ in $\mathrm{g} \mathrm{kg}^{-1}$ ) for Latosols on the SAS in comparison with the Latosols on the VS $\left(183 \leq G b \leq 405\right.$ in $\mathrm{g} \mathrm{kg}^{-1}$ ) (Table 5). We computed the ratio of the kaolinite content to both the kaolinite and gibbsite content $\left(\mathrm{R}_{\mathrm{Kt} / \mathrm{Kt}+\mathrm{Gb}}\right)$. The data indicated that $0.2 \leq \mathrm{R}_{\mathrm{Kt} / \mathrm{Kt}+\mathrm{Gb}} \leq 0.5$ in the Latosols located on the SAS and $0.5 \leq \mathrm{R}_{\mathrm{Kt} / \mathrm{Kt}+\mathrm{Gb}} \leq 0.8$ for those located on the VS (Table 5). The $H m$ content ranged from 0 to 205 in $\mathrm{g} \mathrm{kg}^{-1}$ and $G t$ content from 0 to $178 \mathrm{~g} \mathrm{~kg}^{-1}$ for the $\mathrm{Bw}$ horizons studied (Table 5). The averaged $\mathrm{Hm}$ and $\mathrm{Gt}$ content in the $\mathrm{Bw}$ horizon was respectively 87 and 106 in $\mathrm{g} \mathrm{kg}^{-1}$, on the SAS and 136 and 45 in $\mathrm{g} \mathrm{kg}^{-1}$, on the VS (Table 5). We computed the ratio of the hematite content to both the hematite and goethite content $\left(\mathrm{R}_{\mathrm{Hm} / \mathrm{Hm}+\mathrm{Gt}}\right)$. The results pointed that $0.0 \leq \mathrm{R}_{\mathrm{Hm} / \mathrm{Hm}+\mathrm{Gt}} \leq 0.7$ for the Latosols situated on the SAS, and $0.4 \leq \mathrm{R}_{\mathrm{Hm} / \mathrm{Hm}+\mathrm{Gt}} \leq 1.0$ for those situated on the VS (Table 5).

\subsection{Types of microgranular structure, particle size distribution, and mineralogy}

The analysis of the type of microgranular structure did not show any relationship with the composition of the Bw horizons studied, neither with their particle size distribution (Fig. $5 \mathrm{a}$ and $\mathrm{b}$ ), nor with their mineralogy of the fine fraction (Fig. 5a and c). The Bw horizons of L1, L2, L3, L6 and L10 on the one hand, and those of L5, L7, L8 and L9 on the other hand 
showed kaolinite and gibbsite different contents (Fig. 5c) when the proportion of the types of microgranular structure varied independently of that distinction (Fig. 5a). These results are in line with many former studies that led to contradictory results when the development of the microgranular structure was discussed according to the clay content and clay mineralogy (Bennema et al., 1970; Vidal-Torrado and Lepsch, 1999; Ferreira et al., 1999; Gomes et al., 2004; Viana et al., 2004; Schaefer, 2001 and Schaefer et al., 2004)

\subsection{Microgranular structure development and associated voids}

The types of microgranular structure A, B and C were observed in different proportions in the Bw horizons studied (Table 4). They are characterized by a varying volume of voids between the microaggregates (Fig. 3 and Fig. 4a, b and c) except for L4 where the microgranular structure corresponds to type D with many voids between the clay-coated quartz grains and microaggregates (Fig. $3 \mathrm{~g}$ and $\mathrm{h}$ and Fig. $4 \mathrm{~d}$ ). The volume of intermicroaggregate voids was calculated as follows:

$$
V_{v}^{\text {int } e r}=V_{v}^{\text {total }}+V_{v}^{\text {int } r a}
$$

where $V_{v}^{\text {inter }}$ was the volume of inter-microaggregates voids (in $\mathrm{cm}^{3} \mathrm{~g}^{-1}$ ), $V_{v}^{\text {intra }}$ the volume of intra-microaggregates voids (in $\mathrm{cm}^{3} \mathrm{~g}^{-1}$ ), and $V_{v}^{\text {total }}$, the total volume of voids (in $\mathrm{cm}^{3} \mathrm{~g}^{-1}$ ). The latter was computed as follows:

$$
V_{v}^{\text {total }}=(1 / D b)-(1 / D p)
$$

where $D \mathrm{p}$ was the particle density and equal to the reciprocal of $2.65 \mathrm{~g} \mathrm{~cm}^{3}$. The value of $V_{v}^{\text {int } r a}$ for each $\mathrm{Bw}$ horizon studied was computed by using the relationship recorded by Balbino et al. (2002) for Latosols. The results showed that $0.156 \leq V_{v}^{\text {int } r a} \leq 0.234 \mathrm{~cm}^{3} \mathrm{~g}^{-1}$ and $0.305 \leq V_{v}^{\text {int } e r} \leq 0.585 \mathrm{~cm}^{3} \mathrm{~g}^{-1}$ 
Comparison of $V_{v}^{\text {inter }}$ with the proportion of the different types of microstructure showed that both $V_{v}^{\text {inter }}$ and the surface area proportion of type A were the greatest in L2, L3, L6 and L10 (Fig. 5a; Table 6). On the other hand, this comparison also showed that both $V_{v}^{\text {int } e r}$ and the surface area proportion of type A was the smallest in L1 and L9.

\subsection{Microgranular structure development and biological activity}

Analysis of the distribution of the different types of microgranular structure in microscopy at low magnification showed that type $\mathrm{C}$ corresponds to portions of channels or cavities walls similar to those described by Eschenbrenner (1986) (Fig. 6). Contours of channels and cavities were particularly visible in L1, L5 and L9 (Fig. 6). Thus, type C originates from soil material kneading by termites resulting in coalescent microaggregates forming mechanically stable and water proof walls. On the other hand, the types A and B originate from an infilling activity with microaggregates resulting from fragmentation and burrowing action of termites and possibly of ants, too. The findings of this study are comparable to those of Miklós (1992) and Cooper et al. (2005). These authors also worked on Brazilian Latosols and recorded the microgranular structure as originating partly from biological activity. Holt and Lepage (2000) also discussed soil bioturbation by termites during mound-building and cavities and galleries constructions. These constructions, in a long period of time, modified the soil properties and pedogenesis tends as consequence soil turnover over and soil translocation (Holt and Lepage, 2000). Schaefer (2001) proposed that the Bw horizon microgranular structure of Brazilian Latosols would result from long-term biological activity of termites. Based on this model, the structure of the Latosols studied would originate from long-term action of biotic activity, mainly of termite activity as shown in Figure 7. Such a long-term bioturbation might explain the poor vertical differentiation of the Latosols studied and the lack of relationship between Latosol composition and microgranular structure 
development. The DIRV observed in the soil type studied that also show a microgranular structure of type $\mathrm{C}$ would correspond to remnants of mound, cavities or galleries walls made up of coalesced microaggregates (Table 2 and Fig. 6).

\section{Conclusions}

The Latosols studied showed a compound strong microgranular structure and weak to moderate medium sub-angular blocky structure independently of the landscape position on the South American Surface or Velhas Surface as well as the parental material, except for the Latosol developed on a quartzite. They were classified as gibbsitic-sexquioxic, kaolinitic nonsesquioxid, or kaolinitic-sesquioxid Latosols.. The study revealed several type of microgranular structure with different proportions according to the Latosol studied but without any relationship with their texture and mineralogy. The types of microgranular structure appeared to be related to soil bioturbation conducted mainly by termites, and secondarily by ants. Thus, the weak macrostructure and strong microgranular structure of the Latosols studied, their little vertical differentiation of the horizons, and the lack of clear relationship between their landscape position and parent material characteristics would result from long-term biotic action.

\section{Acknowledgements}

We thank the Empresa Brasileira de Pesquisa Agropecuária (EMBRAPA) for supporting studies of A. Reatto in Orléans, France. This research is part of the project Embrapa Cerrados - IRD, n0203205 (Mapping of the Biome Cerrado Landscape and Functioning of Representative Soils). We also like to acknowledge the support of C. Le Lay (INRA) for assistance in the laboratory. 


\section{References}

Allaby, A., Allaby, M., 2003. A dictionary of Earth Sciences. University Press, Oxford. 619 pp.

Assad, E.D., Sano, E.E., Masutomo, R., Castro, L.H.R., Silva, F.A.M., 1993. Veranicos na região dos cerrados brasileiros: freqüência e probabilidade de ocorrência. Pesquisa Agropecuária Brasileira 28, 993-1002.

Balbino, L. C., Bruand, A., Brossard, M., Guimarães, M. F., 2001. Comportement de la phase argileuse lors de la dessiccation dans dês Ferralsols microagrégés du Brésil: rôle de la microstructure et de la matière organique. Comptes Rendus de l'Académie des Sciences $332,673-680$.

Balbino, L.C., Bruand, A., Brossard, M., Grimaldi, M., Hajnos, M., Guimarães, M.F., 2002. Changes in porosity and microaggregation in clayey Ferralsols of the Brazilian Cerrado on clearing for pasture. European Journal of Soil Science 53, 219-230.

Balbino, L. C., Bruand, A., Cousin, I., Brossard, M., Quétin, P., Grimaldi, M., 2004. Change in the hydraulic properties of a Brazilian clay Ferralsol on clearing for pasture. Geoderma 120, 297-307.

Bennema, J., Jongerius, A., Lemos, R. C., 1970. Micromorphology of some oxic and argillic horizons in south Brazil in relation to weathering sequences. Geoderma 4, 333-355.

Braum, O.P.G., 1971. Contribuição à geomorfologia do Brasil Central. Revista Brasileira de Geografia 32, 3-39.

Bruand, A., Prost R., 1988. Analyse minéralogique quantitative d'un échantillon de sol: utilisation des donnés concernant la composition chimique de l'échantillon. Agronomie $8(1), 15-22$. 
Bruand, A., Cousin, I., Nicoullaud, B., Duval, O., Bégon, J. C., 1996. Backscattered electron scanning images of soil porosity for analyzing soil compaction around roots. Soil Science Society America Journal 60, 895-901.

Bullock, P., Fedoroff, N., Jongerius, A., Stoops, G., Tursina, T., Babel, U., 1985. Handbook for soil thin section description. Waine Research Publications. $152 \mathrm{pp}$.

Camargo, M. N., Kimble, J. M., Beinroth, F. H., 1986. Classification, Characterization and Utilization of Oxisols, Part 2: Field Trip Background, Site and Pedon Descriptions, Analytical Data. In: Proceedings of the Eight International Soil Classification Workshop, Brazil, SNLCS-Embrapa, Soil Management Support Services and Soil Conservation Service-United States Department of Agriculture, University of Puerto Rico. 240 pp.

Cooper, M., Vidal-Torrado, P., Chaplot, V., 2005. Origen of microaggregates in soils with ferralic horizons. Scientia Agricola 62 (3), 256-263.

Embrapa, 1997. Manual de métodos de análise de solo. 2ed. rev. atual. Empresa Brasileira de Pesquisa Agropecuária, Rio de Janeiro-RJ. 212 pp.

Embrapa, 1999. Sistema Brasileiro de Classificação de Solos. Empresa Brasileira de Pesquisa Agropecuária, Rio de Janeiro-RJ. 412 pp.

Eschenbrenner, V., 1986. Contribution des termites à la micro-agrégation des sols tropicaux. Cah. ORSTON, sér. Pédol., vol. XXII, 4, 397-408.

Ferreira, M.M., Fernandes, B., Curi, N., 1999. Mineralogia da fração argila e estrutura de latossolos da região sudeste do Brasil. Revista Brasileira de Ciência do Solo 23, 507-514.

Fitzpatrick, E., 1984. Micromorphology of Soils. Chapman and Hall, University Press, Cambridge. 433 pp.

Gomes, J.B.V., Curi, N., Schulze, D.G., Marques, J.J.G.S.M., Ker, J.C., Motta, P.E.F., 2004. Mineralogia, morfologia e análise microscópica de solos do Bioma Cerrado. Revista Brasileira de Ciência do Solo 28, 679-694. 
Holt, J. A., Lepage, M., 2000. Termites and soil properties. In:Termites: Evolution, Sociality, Symbioses, Ecology. (Abe, T, Bignell, D. E., Higashi, M., Eds). Kluwer Academic Publisher, pp. 389-407.

IUSS Working Group WRB., 2006. World reference base for soil resources 2006. World Soil Resources Reports º 103. FAO, Rome. 128 pp.

Kampf, N., Kamt, E., Schneider, P., 1988. Óxidos de ferro em Latossolos do Brasil Sudeste e Sul,. In: Anais da III Reunião de Classificação, Correlação de Solos e Interpretação de Aptidão Agrícola, Embrapa-SNLCS, Rio de Janeiro-RJ. Série Documentos 12, 153-183.

Ker, J. C., 1998. Latossolos do Brasil: uma revisão. Geonomos 5(1), 17-40.

King, L.C., 1956. A geomorfologia do Brasil Central. Revista Brasileira de Geografia 18(2), 3-39.

Klute, A., 1986. Methods of Soil Analysis, Part 1, Physical and Mineralogical Methods. Amer. Soc. Agronomy and Soil Sci. Soc. Amer., Madison, Wisconsin, USA. 1188 pp.

Köppen, W. P., 1931. Grundriss der Klimakunde. Walter de Gruyter, Berlin. 388pp.

Lemos, R. C., Santos, R. D., 1996. Manual de descrição e coleta de solo no campo. 3 ed. Campinas, Sociedade Brasileira de Ciência do Solo, 84 pp.

Lepsch, I. F., Buol, S. W., 1988. Oxisol-Landscape relationships in Brazil. In: Proceedings of the Eighth International Soil Classification Workshop. Classification, Characterization and Utilization of Oxisols. Part 1: Papers. (Beinroth, F. H., Camargo, M. N., Eswaran, H., Eds). Rio de Janeiro-RJ, pp. 174-189.

Lima, P. C., 1988. Micromorfologia de "horizonte B" de latossolos do Sudeste e Sul do Brasil. In: Anais da III Reunião de Classificação, Correlação de Solos e Interpretação da Aptidão Agrícola. Rio de Janeiro - RJ, EMBRAPA-SNLCS/SBCS. Documentos 12, $391-411$. 
Page, A. L., Miller, R. H., Keeney, D. R., 1982. Methods of Soil Analysis, Part 2, Chemical and Microbiological Properties. Amer. Soc. Agronomy and Soil Sci. Soc. Amer., Madison, Wisconsin, USA. 1159 pp.

Marques, J.J.G.S.M., 2000. Trade element distributions in Brazilian Cerrado soils at the landscape and micrometer scales, Ph. D. Thesis, Purdue University, USA. (available at http://www.dcs.ufla.br/marques) (visited in October 2008).

Marques, J. J., Schulge, D. G., Curi, N., Merttzman, S. A., 2004. Major element geochemistry and geomorphic relationships in Brazilian Cerrado soils. Geoderma 119, 179-195.

Miklós, A. A. de W., 1992. Biodynamique d'une couverture pédologique dans la région de Botucatu, Brésil. PhD-thesis. Université d'Paris VI -Paris, France. 438p.

Motta, P. E. F., Carvalho Filho, A., Ker, J. C., Pereira, N. R., Carvalho Junior, W., Blancaneaux, P., 2002. Relações solo-superfície geomórfica e evolução da paisagem em uma área do Planalto Central Brasileiro. Pesquisa Agropecuária Brasileira 37, 869-878.

Reatto, A., Martins, E.S., Guimarães, E.M., Spera, S.T., Correia, J.R., 2000. Variabilidade mineralógica de latossolos da área da Embrapa Cerrados em relação aos do Bioma Cerrado. Boletim de Pesquisa Embrapa Cerrados 20, 1-29.

Reatto, A., Bruand. A., Silva E. M., Martins E. S., Brossard M., 2007. Hydraulic properties of the diagnostic horizon of Latosols of a regional topossequence across the Brazilian Central Plateau. Geoderma 139, 51-59.

Reatto, A., Bruand. A., Martins, E. S., Muller, F., Silva, E. M., Carvalho Jr, O. A., Brossard, M., 2008. Variation of the kaolinite and gibbsite content at regional and local scale in the Latosols of the Brazilian Central Plateau. C. R. Geoscience xx, xx-xx. (article in press). http://dx.doi.org/10.1016/j.crte.2008.07.006 
Resende, M., Bahia Filho, A.F.C., Braga, J.M., 1987. Mineralogia da argila de latossolos a partir do teor total de óxidos do ataque sulfúrico. Revista Brasileira de Ciência do Solo 11, $17-23$.

Resende, M., Santana, D.P., 1988. Uso das Relações Ki e Kr na estimativa da mineralogia para classificação dos Latossolos. In: Anais da 3. Reunião de Classificação, Correlação de Solos e Interpretação de Aptidão Agrícola. Rio de Janeiro-RJ, EMBRAPA-SNLCS/SECS. Documentos 12, 225-229.

Santana, D.P., 1984. Soil formation in a toposequence of oxisols from Patos de Minas region, Minas Gerais, State, Brasil. Ph. D. Thesis. Purdue University, West Lafayette. 129 pp.

Schaefer, C. E. R., 2001. Brazilian latosols and their B horizon microstructure as long-term biotic constructs. Australian Journal Soil Research 39, 909-926.

Schaefer, C. E. R., Ker, J. C., Gilkes, R. J., Campos, L. M., Saadi, A., 2002. Pedogenesis on the uplands of the Diamantina Plateau, Minas Gerais, Brazil: a chemical and micropedological study. Geoderma 107, 243-269.

Schaefer, C. E. R., Gilkes, R. J., Fernandes, R. B. A., 2004. EDS/SEM study on microaggregates of Brazilian Latosols, in relation to $\mathrm{P}$ adsorption and clay fraction attributes. Geoderma 123, 69-81.

Silva, A.V., Farias, M.F., Reatto A., Martins, E.S., Brossard, M., Becquer, T., Oliveira, O.R., 2005. Caracterização e distribuição das principais classes pedológicas do Planalto Central Brasileiro. In: Anais do XXV Congresso Brasileiro de Ciência do Solo. SBCS, Recife-PE, CD-ROM.

Soil Survey Staff, 2006. Keys to Soil Taxonomy. 8 ed. United States Department of Agriculture, Natural Resources Conservation Service, Washington. 326 pp. 
Stoops, G., 2003. Guidelines for analysis and description of soil and regolith thin sections. Soil Science of America, Inc. Madison, Wisconsin, USA. 184 pp.

Vettori, L., 1959. As relações $\mathrm{Ki}$ e $\mathrm{Kr}$ na fração argila e na terra fina. In: Anais do VII Congresso Brasileiro de Ciência do Solo. Piracicaba-SP. SBCS. p. 35.

Viana, J. H. M., Fernandes Filho, E. I., Schaefer, C. E. G. R., 2004. Efeitos de ciclos de umedecimento e secagem na reorganização da estrutura microgranular de Latossolos. Revista Brasileira de Ciência do Solo 28,11-19.

Vidal-Torrado, P. and Lepsh, I. F., 1999. Relações material de origem/solo e pedogênese em uma sequência de solos predominantemente argilosos e latossólicos sobre psamitos na depressão periférica paulista. Revista Brasileira de Ciência do Solo 23, 357-369.

Volland-Tuduri, N., Brossard, M., Bruand, A., Garreau, H., 2004. Direct analysis of microaggregates shrinkage for drying: Application to microaggregates from a Brazilian clayed Ferralsol. Comptes Rendus de l'Académie des Sciences 336, 1017-1024.

Volland-Tuduri, N., Bruand, A., Brossard, M., Balbino, L. C., Oliveira, M. I. L., Martins, E. S., 2005a. Mass proportion of migroaggregates and bulky density in a Brazilian clayed Oxisol. Soil Science Society American Journal 69, 1559-1564.

Volland-Tuduri, N., 2005b. Nature et mode d`assemblage des constituintes minèraux et organiques dans des Ferralsols de la région des Cerrados (Brésil) evolution après mise en culture. PhD-thesis. Université d’Orléans-Orléans, France. (available at http://tel.archivesouvertes.fr/tel-00009347/fr/) (visited in October 2008). 


\section{Figures}

2 Figure 1

3 Distribution of the Latosols on the Brazilian Central Plateau.

4

$5 \quad$ Figure 2

6 Location of the ten Latosols studied (L) on each geomorphic surface along a regional 7 toposequence across the Brazilian Central Plateau.

$9 \quad$ Figure 3

10 Microstructure of the Bw horizon observed in optical microscopy (natural light): $\mathrm{a}$ and $\mathrm{b}$,

11 strong microgranular structure with highly separated microaggregates in L1; c and d, strong 12 microgranular structure with moderately separated microaggregates in L9; e and f, moderate 13 microagranular structure with coalesced microaggregates in L5; $\mathrm{g}$ and $\mathrm{h}$, compound 14 microgranular structure and pellicular grain microstructure in L4.

16 Figure 4

17 Microstructure of the $\mathrm{Bw}$ horizon observed in scanning electron microscopy using the 18 backscattered electrons: a, strong microgranular structure with highly to moderately separated 19 microaggregates in L1; b, strong microgranular structure with moderately to weakly separated 20 microaggregates in L7; c, moderate to weak microagranular structure with coalesced 21 microaggregates in L5; d, compound microgranular structure and pellicular grain 22 microstructure in L4.

Figure 5 
25 Different types of microstructure (a), particle size distribution (b) and clay mineralogy (c) for

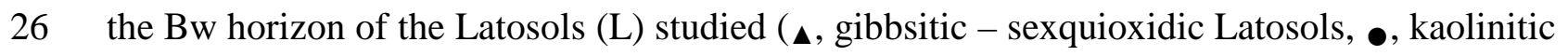

27 - sexquioxidic and $\circ$, kaolinitic - non sexquioxidic Latosols).

29 Figure 6

30 Distribution of the different types of microgranular structure (types A, B and C) in the diagnostic 31 horizons (Bw) of L1 (a), L5 (b), L2 (c) and L9 (d).

$33 \quad$ Figure 7

34 Model based on long-term termite activity for the Latosols studied showing the accumulated 35 action of bioturbation on the structure with time. 


\section{Tables}

Table 1

General characteristics of the Latosols (L) studied (modified after Reatto et al., 2007; Reatto et al., 2008)

\section{Table 2}

Field morphological descriptions of the Latosols (L) studied

Table 3

Physical and chemical characteristics of the diagnostic horizons (Bw) of the Latosols (L) studied

Table 4

Micromorphological analyses of the diagnostic horizons $(\mathrm{Bw})$ of the Latosols (L) studied

Table 5

Mineralogy of the diagnostic horizons (Bw) of the Latosols (L) studied.

Table 6

Volume of voids resulting from the assemblage of the microaggregates (inter-aggregates voids) for the Bw horizons studied. 


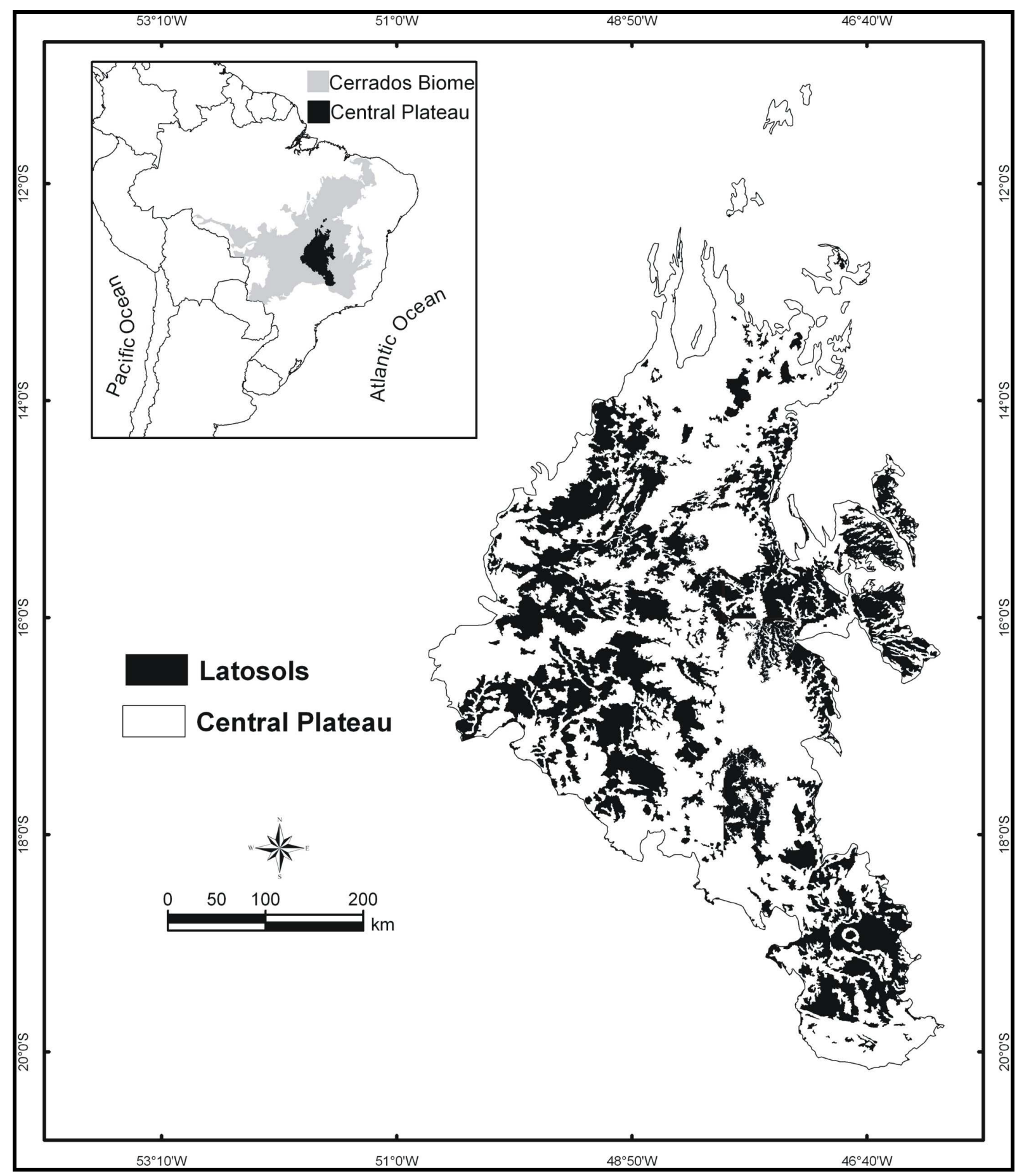

Fig. 1 - Distribution of the Latosols on the Brazilian Central Plateau. 


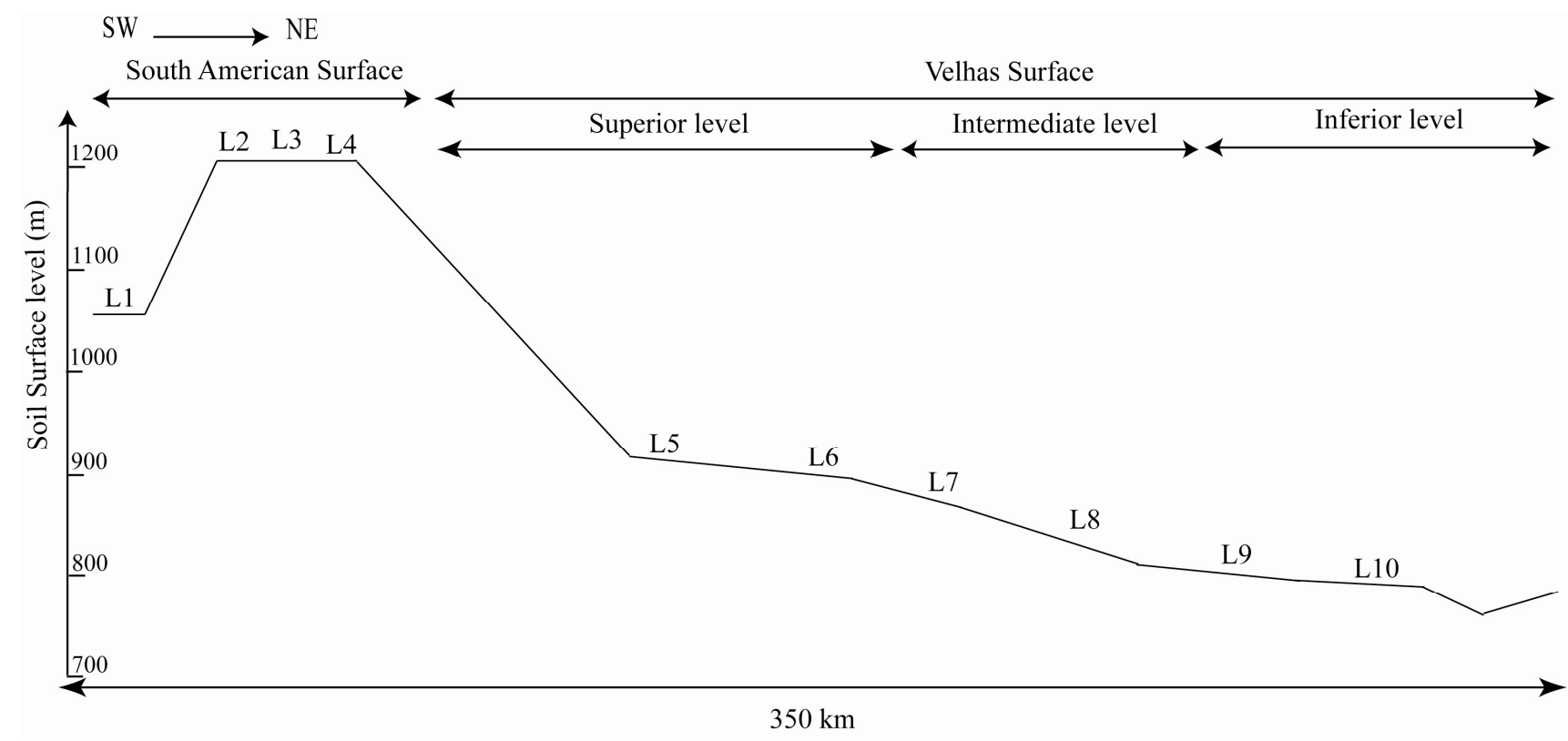

Fig. 2 - Location of the ten Latosols studied (L) on each geomorphic surface along a regional toposequence across the Brazilian Central Plateau. 


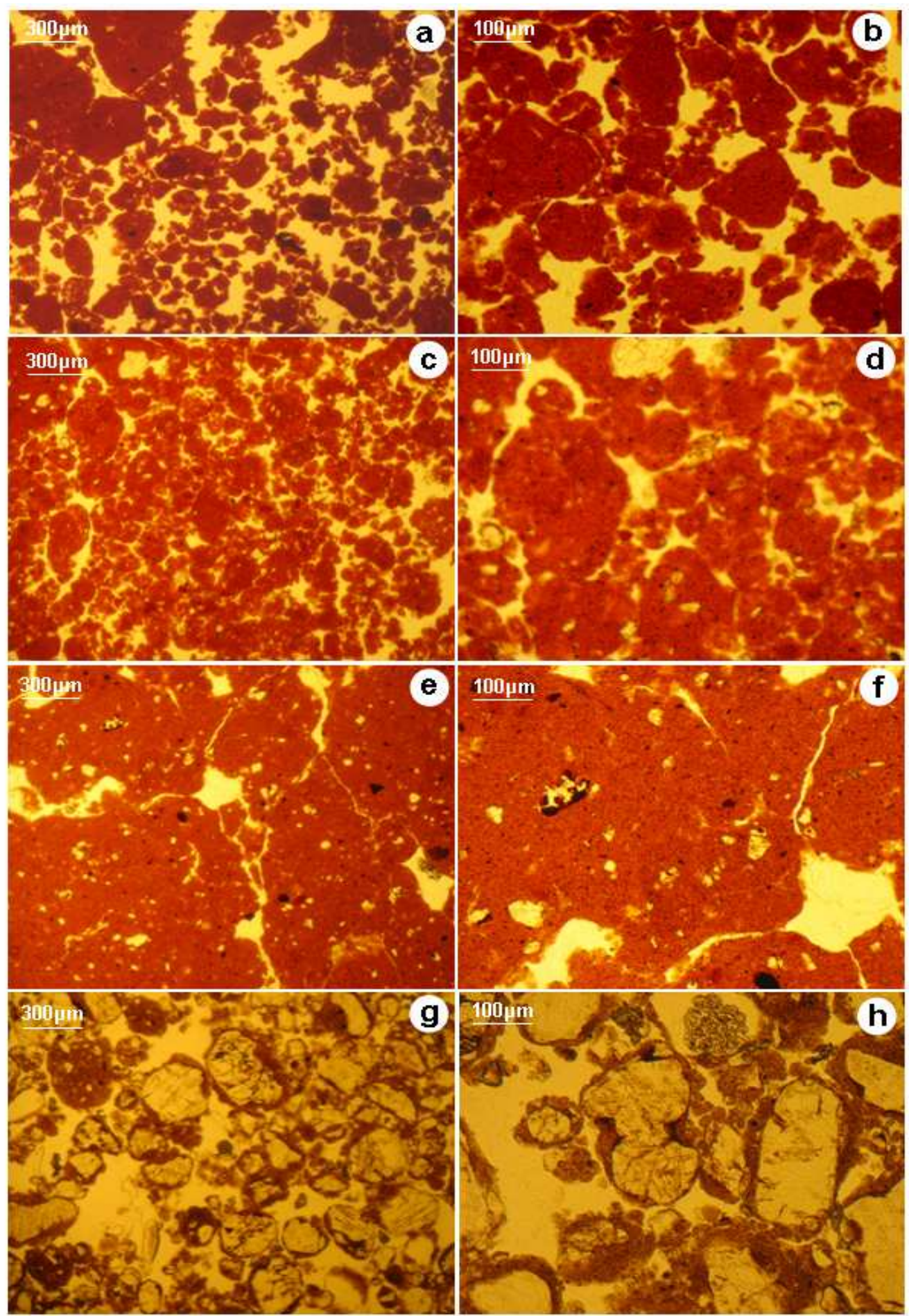

Fig. 3 - Microstructure of the $\mathrm{Bw}$ horizon observed in optical microscopy (natural

light): $a$ and $b$, strong microgranular structure with highly separated microaggregates in L1; $\mathrm{c}$ and $\mathrm{d}$, strong microgranular structure with moderately separated microaggregates in L9; e and f, moderate microagranular structure with coalesced microaggregates in L5; $\mathrm{g}$ and $\mathrm{h}$, compound microgranular structure and pellicular grain microstructure in L4. 

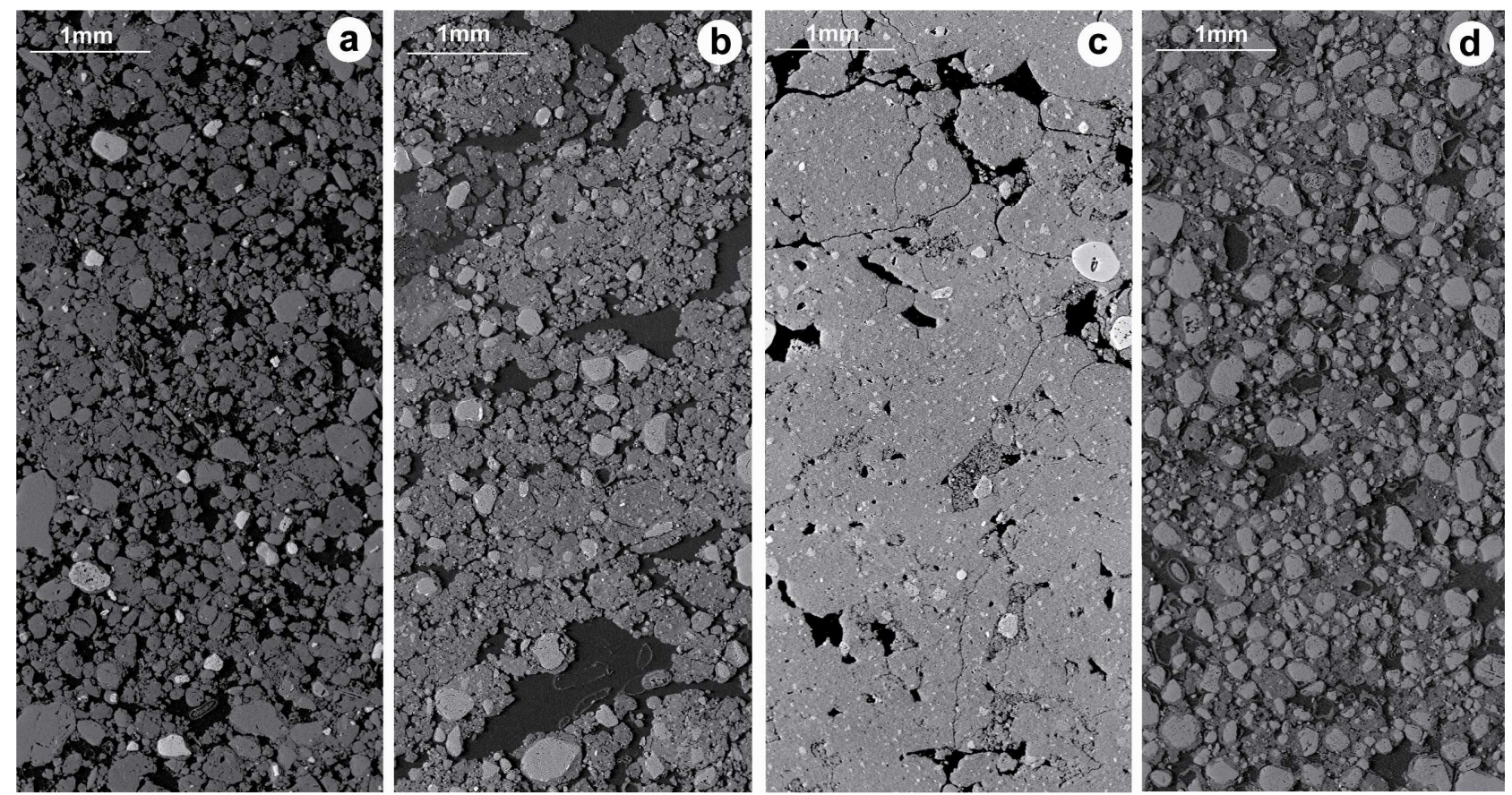

Fig. 4 - Microstructure of the Bw horizon observed in scanning electron microscopy using the backscattered electrons: a, strong microgranular structure with highly to moderately separated microaggregates in L1; b, strong microgranular structure with moderately to weakly separated microaggregates in L7; c, moderate to weak microagranular structure with coalesced microaggregates in L5; d, compound microgranular structure and pellicular grain microstructure in L4. 

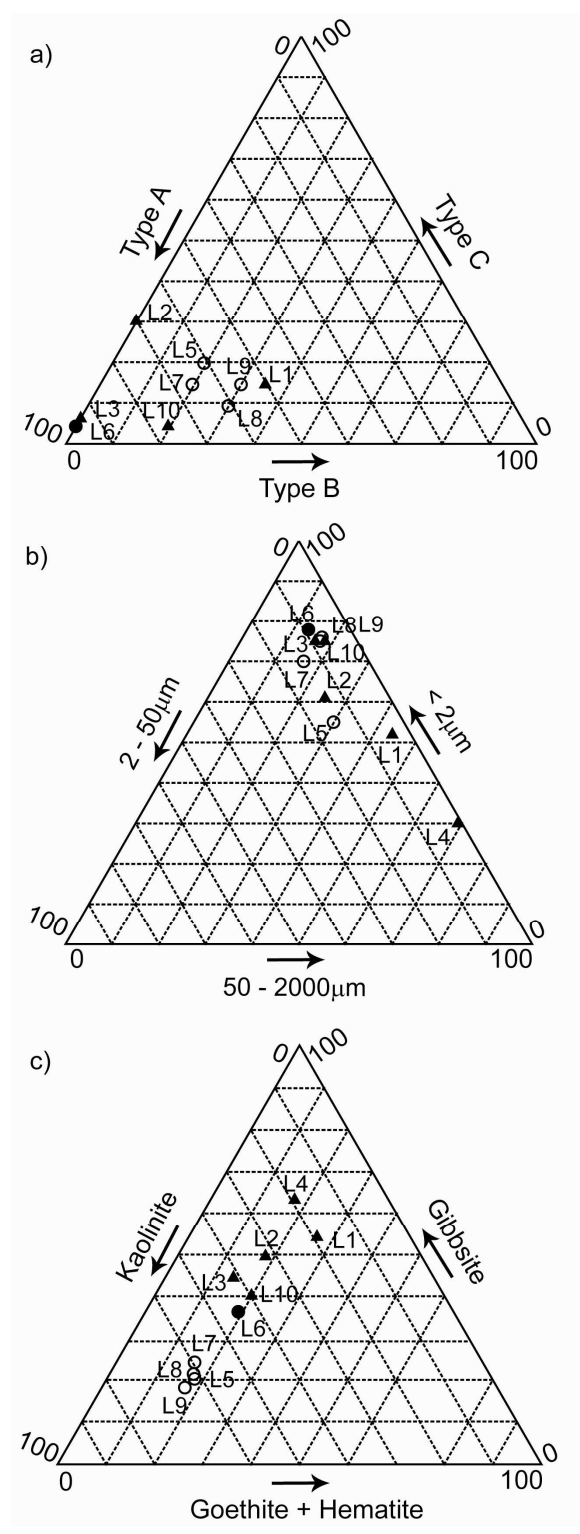

Fig. 5 - Different types of microstructure (a), particle size distribution (b) and clay mineralogy (c) for the Bw horizon of the Latosols (L) studied ( $\mathbf{\Delta}$, gibbsitic - sexquioxidic Latosols, •, kaolinitic - sexquioxidic and, , kaolinitic - non sexquioxidic Latosols). 


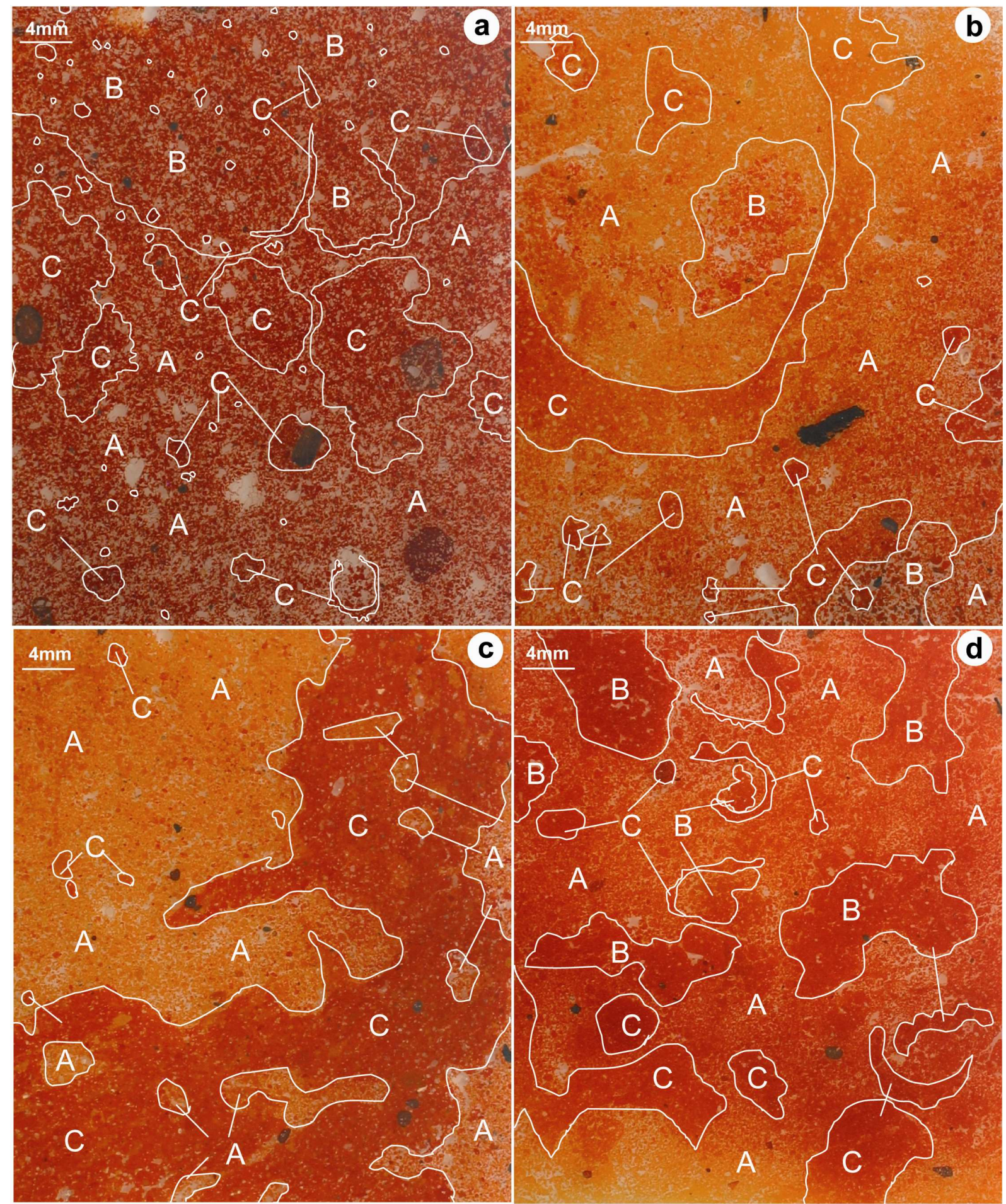

Fig. 6 - Distribution of the different types of microgranular structure (types A, B and C) in the diagnostic horizons (Bw) of L1 (a), L5 (b), L2 (c) and L9 (d). 


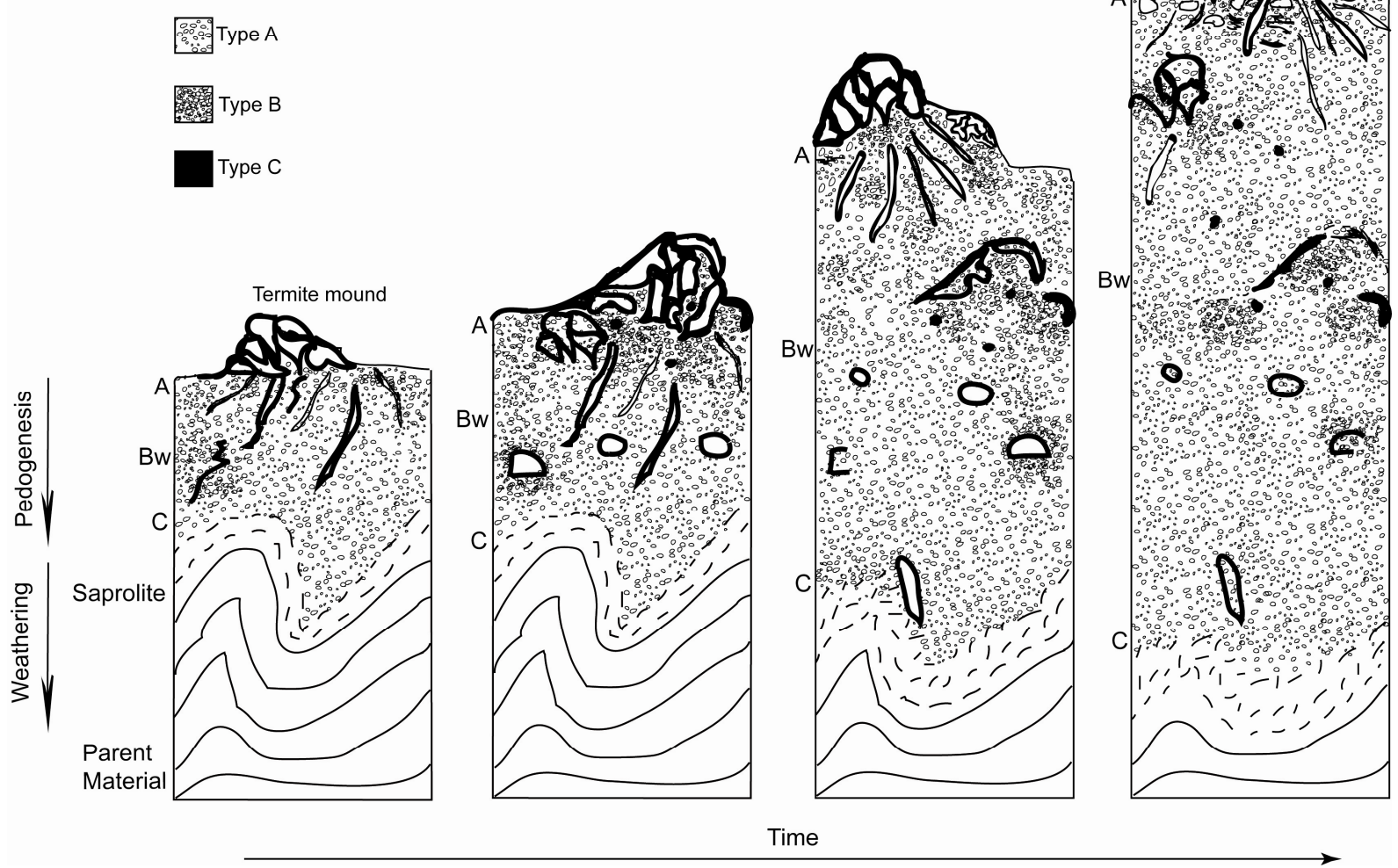

Fig. 7 - Model based on long-term termite activity for the Latosols studied showing the accumulated action of bioturbation on the structure with time. 
Table 1

General characteristics of the Latosols (L) studied (modified after Reatto et al., 2007; Reatto et al., 2008)

\begin{tabular}{|c|c|c|c|c|c|c|c|c|c|c|}
\hline Latosols & $\begin{array}{l}\text { Geographical } \\
\text { Coordinates }\end{array}$ & $\begin{array}{l}\text { Geomorphic } \\
\text { Surface }\end{array}$ & Soil type & $\begin{array}{l}\text { Altitude } \\
(\mathrm{m})\end{array}$ & $\begin{array}{c}\text { Position } \\
\text { along the } \\
\text { toposequence }\end{array}$ & $\begin{array}{l}\text { Slope } \\
\text { Length } \\
(\mathrm{Km})\end{array}$ & $\begin{array}{l}\text { Declivity } \\
(\%)\end{array}$ & Geology & Lithology & Parent Material \\
\hline L1 & $\begin{array}{l}\text { S } 66^{\circ} 60^{\prime} 77^{\prime}, \\
\text { W } 81^{\circ} 60^{\prime} 187^{\prime},\end{array}$ & South America & $\begin{array}{l}\text { Red Latosol }^{(1)} \\
\text { Rhodic Acrustox }^{(2)} \\
\text { Rhodic Ferralsol }^{(3)}\end{array}$ & 1,050 & Median & 3 & $<1$ & $\begin{array}{l}\text { Metamorphic Rocks- Complex } \\
\text { Goiano - (Anápolis - Itauçu) } \\
\text { and metaclastic rocks - Group } \\
\text { Araxá - Superior Precambrian }\end{array}$ & Granulite & Mafic granulite \\
\hline L2 & $\begin{array}{l}\text { S } 15^{\circ} 37^{\prime} 127^{\prime}, \\
\text { W } 47^{\circ} 45^{\prime} 576^{\prime},\end{array}$ & South America & $\begin{array}{l}\text { Red Latosol }^{(1)} \\
\text { Typic Acrustox } \\
\text { Orthic Ferralsol }^{(3)} \\
\text { Yellow Latosol }^{(1)}\end{array}$ & 1,200 & Median & 5 & 2 & $\begin{array}{l}\text { Clastic rocks - Paranoá Group - } \\
\text { Superior Precambrian }\end{array}$ & $\begin{array}{c}\text { Sandy } \\
\text { Metarithimite }\end{array}$ & $\begin{array}{l}\text { Lateritic crusts and } \\
\text { saprolite Sandy } \\
\text { Metarithimite } \\
\text { Lateritic crusts and }\end{array}$ \\
\hline L3 & $\begin{array}{l}\text { S } 15^{\circ} 36^{\prime} 919^{\prime \prime} \\
\text { W } 47^{\circ} 45^{\prime} 78^{\prime \prime}\end{array}$ & South America & $\begin{array}{l}\text { Xanthic Acrustox } \\
\text { Xanthic Ferralsol }^{(2)} \\
\text { Plinthic Yellow }^{(1)} \\
\text { Latosol }^{(1)}\end{array}$ & 1,190 & Median & 5 & 2 & $\begin{array}{c}\text { Clastic rocks - Paranoá Group - } \\
\text { Superior Precambrian }\end{array}$ & $\begin{array}{c}\text { Sandy } \\
\text { Metarithimite }\end{array}$ & $\begin{array}{l}\text { saprolite Sandy } \\
\text { Metarithimite }\end{array}$ \\
\hline L4 & $\begin{array}{l}\text { S } 15^{\circ} 36^{\prime} 320^{\prime \prime} \\
\text { W } 47^{\circ} 44^{\prime} 148^{\prime \prime}\end{array}$ & South America & $\begin{array}{l}\text { Plinthic Acrustox } \\
\text { Plinthic Ferralsol }^{(2)} \\
\text { Red Latosol }^{(1)}\end{array}$ & 1,180 & Down & 12 & 3 & $\begin{array}{c}\text { Clastic rocks - Paranoá Group - } \\
\text { Superior Precambrian }\end{array}$ & Quartzite & $\begin{array}{l}\text { Lateritic crusts and } \\
\text { saprolite Quartzite }\end{array}$ \\
\hline L5 & $\begin{array}{l}\text { S } 15^{\circ} 36^{\prime} 502^{\prime}, \\
\text { W } 47^{\circ} 42^{\prime} 813^{\prime},\end{array}$ & $\begin{array}{l}\text { Velhas, } \\
\text { Superior level }\end{array}$ & $\begin{array}{l}\text { Typic Acrustox } \\
\text { Orthic Ferralsol }^{(2)}\end{array}$ & 920 & Median-up & 12 & $<1$ & $\begin{array}{c}\text { Clastic rocks - Paranoá Group - } \\
\text { Superior Precambrian }\end{array}$ & $\begin{array}{c}\text { Clayed } \\
\text { Metarithimite }\end{array}$ & $\begin{array}{l}\text { Colluvial } \\
\text { Sediment }\end{array}$ \\
\hline L6 & $\begin{array}{l}\text { S } 15^{\circ} 31^{\prime} 450^{\prime \prime} \\
\text { W } 47^{\circ} 41^{\prime} 90^{\prime \prime}\end{array}$ & $\begin{array}{l}\text { Velhas, } \\
\text { Superior level }\end{array}$ & $\begin{array}{l}\text { Red Latosol }^{(1)} \\
\text { Rhodic Acrustox }^{(2)} \\
\text { Rhodic Ferralsol }^{(3)}\end{array}$ & 880 & Down & 20 & 6 & $\begin{array}{l}\text { Pelitic rocks - Paranoá Group - } \\
\text { Superior Precambrian }\end{array}$ & Metapelite & $\begin{array}{l}\text { Lateritic crusts and } \\
\text { saprolite Metapelite }\end{array}$ \\
\hline L7 & $\begin{array}{l}\text { S } 15^{\circ} 13^{\prime} 24,2^{\prime \prime} \\
\text { W } 47^{\circ} 42^{\prime} 14,7^{\prime}\end{array}$ & $\begin{array}{l}\text { Velhas, } \\
\text { Intermediate level }\end{array}$ & $\begin{array}{c}\text { Red-Yellow } \\
\text { Latosol }^{(1)} \\
\text { Typic Acrustox } \\
\text { Orthic Ferralsol }^{(3)} \\
\text { Red Latosol }^{(1)}\end{array}$ & 820 & Median-up & 20 & 2 & $\begin{array}{l}\text { Pelitic rocks - Paranoá Group - } \\
\text { Superior Precambrian }\end{array}$ & Metapelite & $\begin{array}{l}\text { Colluvial } \\
\text { Sediment }\end{array}$ \\
\hline L8 & $\begin{array}{l}\text { S } 15^{\circ} 13^{\prime} 23,3^{\prime}, \\
\text { W } 47^{\circ} 42^{\prime} 5,2^{\prime}\end{array}$ & $\begin{array}{l}\text { Velhas, } \\
\text { Intermediate level }\end{array}$ & $\begin{array}{l}\text { Rhodic Acrustox } \\
\text { Rhodic Ferralsol }^{(2)} \\
\text { Red Latosol }^{(1)}\end{array}$ & 805 & Median-down & 7 & 2 & $\begin{array}{l}\text { Pelitic rocks - Paranoá Group } \\
\text { Superior Precambrian } \\
\text { Pelitic rocks and limestone - }\end{array}$ & Metapelite & $\begin{array}{c}\text { Colluvial } \\
\text { Sediment } \\
\text { Saprolite Metapelite }\end{array}$ \\
\hline L9 & $\begin{array}{l}\text { S } 15^{\circ} 11^{\prime} 183^{\prime \prime} \\
\text { W } 47^{\circ} 43^{\prime} 680^{\prime},\end{array}$ & $\begin{array}{c}\text { Velhas, } \\
\text { Inferior level }\end{array}$ & $\begin{array}{l}\text { Rhodic Acrustox } \\
\text { Rhodic Ferralsol }^{(3)} \\
\text { Red Latosol }^{(1)}\end{array}$ & 785 & Median-up & 15 & $<1$ & $\begin{array}{l}\text { Paranoá Group } \\
\text { Superior Precambrian }\end{array}$ & $\begin{array}{l}\text { Metapelite and } \\
\text { limestone }\end{array}$ & $\begin{array}{l}\text { and } \\
\text { limestone }\end{array}$ \\
\hline L10 & $\begin{array}{l}\text { S } 15^{\circ} 14^{\prime} 080^{\prime}, \\
\text { W } 47^{\circ} 46^{\prime} 372^{\prime},\end{array}$ & $\begin{array}{c}\text { Velhas, } \\
\text { Inferior level }\end{array}$ & $\begin{array}{l}\text { Rhodic Acrustox } \\
\text { Rhodic Ferralsol }^{(3)}\end{array}$ & 760 & Dow & 15 & 7 & $\begin{array}{l}\text { Limestone and } \\
\text { lacustrine sediment of Terciary }\end{array}$ & $\begin{array}{l}\text { Lacustrine } \\
\text { limestrone }\end{array}$ & $\begin{array}{l}\text { Colluvial } \\
\text { Sediment }\end{array}$ \\
\hline
\end{tabular}

Geographical Coordinates: measured with a Global Positioning System (GPS); Altitude: measured with an altimeter; Soil Type: (1) Brazilian Soil Taxonomy (Embrapa, 1999), (2) Soil Taxonomy

(Soil Survey Staff, 2006), (3) World Reference Base (IUSS Working Group WRB., 2006). 
Table 2

Field morphological descriptions of the Latosols (L) studied

\begin{tabular}{|c|c|c|c|c|c|c|c|c|}
\hline \multirow{3}{*}{ Latosol } & \multirow{3}{*}{ Horizon } & \multirow{3}{*}{$\begin{array}{l}\text { Depth } \\
\mathrm{cm}\end{array}$} & \multicolumn{2}{|c|}{ Matrix } & \multirow{3}{*}{ Compound Structure } & \multirow{3}{*}{ DIRV } & \multicolumn{2}{|c|}{ Biological macrovoids } \\
\hline & & & Munse & 1 Color & & & & channels and cavities \\
\hline & & & dry & wet & & & roots & termite or ant activity \\
\hline \multicolumn{9}{|c|}{ Red Latosol $^{(1)}-$ Rhodic Acrustox $^{(2)}-$ Rhodic Ferralsol $^{(3)}$} \\
\hline \multirow[t]{5}{*}{ L1 } & A & $0-20$ & $5 Y R 4 / 4$ & $2.5 \mathrm{YR} 3 / 3$ & $(5) 2 \mathrm{f}-\mathrm{mSBK}$ & $(+-) \mathrm{fD}$ & $(+++) \mathrm{fCH}$ & $(+++) \mathrm{fCV}$ \\
\hline & $\mathrm{AB}$ & $20-40$ & $5 Y R 4 / 6$ & $2.5 \mathrm{YR} 3 / 4$ & (3)3c-vcSBK; (4)3-2f-mSBK & $(+) \mathrm{fD}$ & $(+++) \mathrm{fCH}$ & $(++++) f-m C V$ \\
\hline & BA & $40-60$ & $2.5 \mathrm{YR} 4 / 6$ & $2.5 \mathrm{YR} 3 / 4$ & (2)2cSBK; (3)2-1f-mSBK; (4)3fSBK; (3)2-1f-vfGR & $(++) \mathrm{fD}$ & $(++) \mathrm{fCH}$ & $(++) \mathrm{fCV}$ \\
\hline & $\mathrm{Bw}_{1}$ & $60-100$ & $2.5 \mathrm{YR} 4 / 6$ & $2.5 Y R 3 / 4$ & (2)1f-mSBK; (2)1-2cGR; (4)3f-vfGR & $(++) v f D$ & $(+) \mathrm{fCH}$ & $(+++) \mathrm{fCV}$ \\
\hline & $\mathrm{Bw}_{3}$ & $160-200+$ & $2.5 \mathrm{YR} 4 / 8$ & $2.5 \mathrm{YR} 3 / 4$ & (2)1mSBK; (3)1f-mGR; (4)3vfGR & $(++++) \mathrm{vf}-\mathrm{fD}$ & $(+-) \mathrm{fCH}$ & no \\
\hline & & & & & Red Latosol ${ }^{(1)}-$ Typic Acrustox $^{(2)}$ - Orthic Ferralsol ${ }^{(3)}$ & & & \\
\hline \multirow[t]{5}{*}{ L2 } & A & $0-15$ & 7.5YR 3/4 & $5 Y R 3 / 3$ & (1)3cSBK; (5)3fGR & $(+-) \mathrm{fD}$ & $(+) \mathrm{fCH}$ & no \\
\hline & $\mathrm{AB}$ & $15-35 / 40$ & 7.5 YR 5/6 & $5 Y R 4 / 4$ & (1)3cSBK; (4)3m-fSBK; (4)3fGR & $(++++) \mathrm{vcLC}$ & no & no \\
\hline & BA & $35 / 40-60 / 80$ & 5YR 5/8 & $2.5 \mathrm{YR} 4 / 6$ & (1)2c-mSBK; (2)2fSBK; (5)2f-vfGR & $(+++) \mathrm{vcD} ;(++) \mathrm{mLC}$ & $(+) \mathrm{fCH}$ & no \\
\hline & $\mathrm{Bw}_{1}$ & $60 / 80-115 / 120$ & 5 YR $5 / 6$ & $2.5 \mathrm{YR} 4 / 8$ & (1)1cSBK; (3)1fSBK; (4)2-3f-vfGR & $(++) \mathrm{f} D$ & no & $(+) \mathrm{cCV}$ \\
\hline & $\mathrm{Bw}_{2}$ & $115 / 120-200+$ & 5 YR 5/6 & $2.5 \mathrm{YR} 4 / 8$ & (1)1cSBK; (5)3f-vfGR & no & no & no \\
\hline \multicolumn{9}{|c|}{ Yellow Latosol $^{(1)}-$ Xanthic Acrustox $^{(2)}-$ Xanthic Ferralsol $^{(3)}$} \\
\hline \multirow{5}{*}{ L3 } & $\mathrm{AB}$ & $20 / 25-50 / 70$ & $10 \mathrm{YR} 6 / 4$ & 10YR 5/6 & (2)3c-mSBK; (4)3fBSK; (4)2-3fGR & $(++++) f-m D$ & no & no \\
\hline & BA & $50 / 70-75 / 95$ & 10YR6/6 & 10YR 6/6 & (2)2c-mSBK; (2)2fSBK; (4)2fGR & $(+++) \mathrm{fD}$ & no & no \\
\hline & $\mathrm{Bw}_{1}$ & $75 / 95-130$ & 10YR 6/6 & 10YR 5/8 & (2)3-2cSBK; (2)2mSBK; (2)2-1fSBK; (4)3f-vfGR & $(++) f D$ & no & no \\
\hline & $\mathrm{Bw}_{2}$ & $130-180$ & 10YR 6/6 & 10YR 6/6 & (2)2-1cSBK; (5)3f-vfGR & $(+-) f L C$ & no & no \\
\hline & $\mathrm{Bw}_{3}$ & $180-220+$ & $7.5 Y R 7 / 6$ & 7.5 YR $5 / 6$ & (3) $1 \mathrm{cSBK} ; 2-1 \mathrm{~m}$ SBK; (4)3f-vfGR & $(+) \mathrm{fLC}$ & no & no \\
\hline \multicolumn{9}{|c|}{$\underline{\text { Plinthic Yellow Latosol }}{ }^{(1)}-$ Plintic Acrustox ${ }^{(2)}-$ Plinthic Ferralsol ${ }^{(3)}$} \\
\hline \multirow[t]{5}{*}{ L4 } & A & $0-18$ & $2.5 Y 5 / 4$ & 10YR 3/4 & (0)3-2cSBK; (2)2-1f-mSBK; (3)1fSBK; (4)1f-mGR & no & $(++++) f-v f C H$ & no \\
\hline & $\mathrm{AB}$ & $18-30$ & 2.5 YR $6 / 6$ & 10YR 4/4 & (3)2-1m-cSBK; (2)2f-mSBK; (4)2f-vfGR & no & $(+++) f-v f C H$ & no \\
\hline & BA & $30-60$ & 2.5 YR6/6 & 10YR 5/6 & (3)2-1f-mSBK; (2)2-1fSBK; (3)2fGR; (4)1f-vfGR & no & $(+) \mathrm{fCH}$ & no \\
\hline & $\mathrm{Bw}_{1}$ & $60-110$ & 10YR7/8 & 10YR 5/8 & (2)1cSBK; (1)1f-mSBK; (5)2f-vfGR & no & $(+-) \mathrm{fCH}$ & no \\
\hline & $\mathrm{Bw}_{2}$ & $110-180+$ & 10YR 7/8 & 10YR 5/8 & (2)1f-mSBK; (5)2f-vfGR & no & $(+-) \mathrm{fCH}$ & no \\
\hline
\end{tabular}


Cont...Table 2 - Field morphological descriptions of the Latosols studied

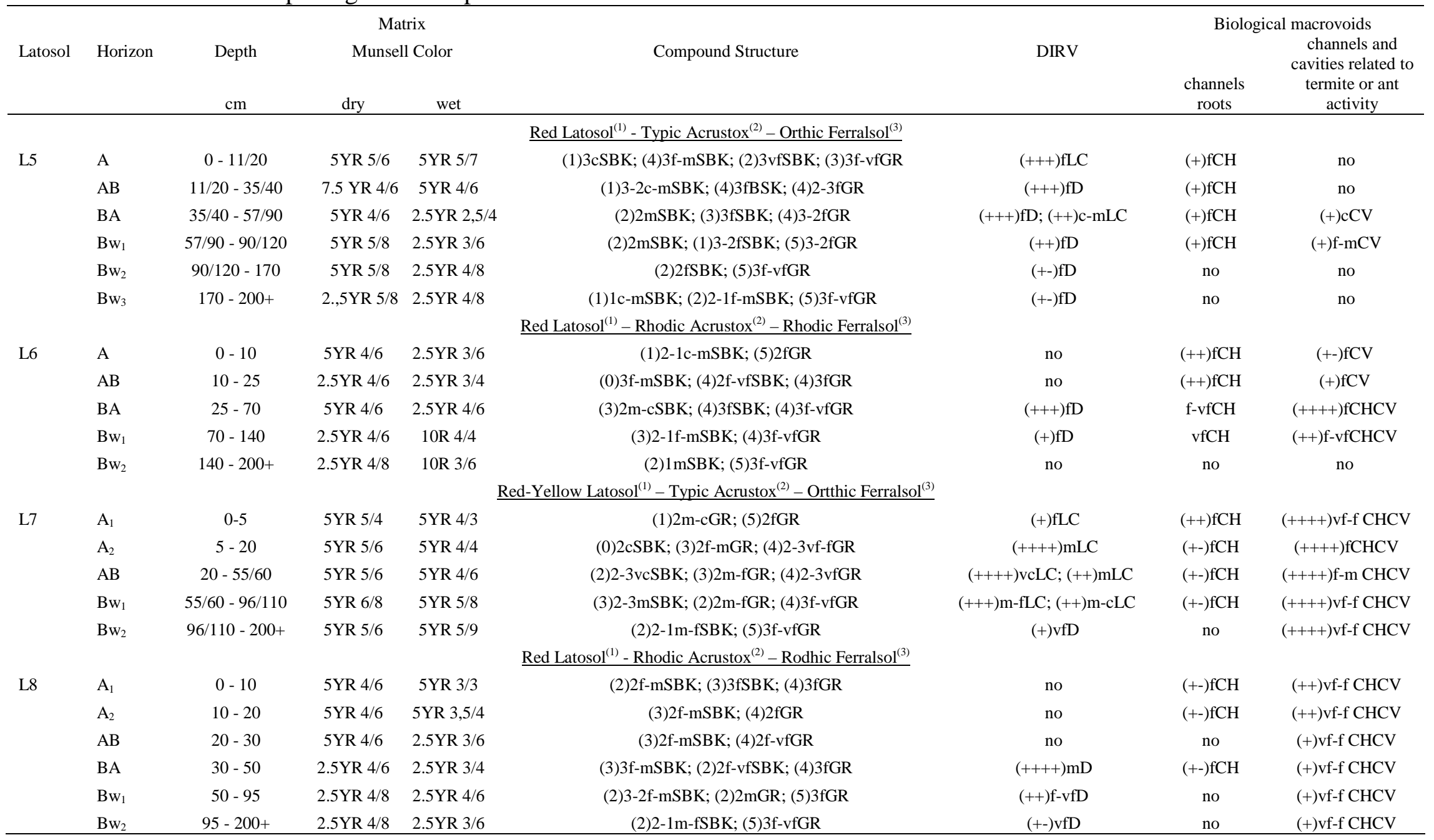


Cont...Table 2 - Field morphological descriptions of the Latosols studied

\begin{tabular}{|c|c|c|c|c|c|c|c|c|}
\hline \multirow[t]{2}{*}{ Latosol } & \multirow[t]{2}{*}{ Horizon } & \multirow{2}{*}{$\begin{array}{l}\text { Depth } \\
\mathrm{cm}\end{array}$} & \multicolumn{2}{|c|}{$\begin{array}{c}\text { Matrix } \\
\text { Munsell Color }\end{array}$} & \multirow[t]{2}{*}{ Compound Structure } & \multirow[t]{2}{*}{ DIRV } & \multicolumn{2}{|c|}{$\begin{array}{l}\text { Biological macrovoids } \\
\text { channels and cavities } \\
\text { related to }\end{array}$} \\
\hline & & & dry & wet & & & $\begin{array}{l}\text { channels } \\
\text { roots }\end{array}$ & $\begin{array}{l}\text { termite or ant } \\
\text { activity }\end{array}$ \\
\hline \multirow{3}{*}{ L9 } & & & & & Red Latosol $^{(1)}-$ Rhodic Acrustox $^{(2)}-$ Rodhic Ferralsol $^{(3)}$ & & & \\
\hline & A & $0-15 / 20$ & $5 \mathrm{YR} 4 / 6$ & $2.5 \mathrm{YR} 3 / 4$ & (0)2c-mSBK; (3)2f-mSBK; (4)2fGR & no & $(+-) \mathrm{fCH}$ & no \\
\hline & $\mathrm{AB}$ & $15 / 20-35 / 40$ & $5 \mathrm{YR} 4 / 6$ & $2.5 Y R 3 / 6$ & (3)3c-mSBK; (3)3fBSK; (4)3fGR & $(+++) \mathrm{mD}$ & $(+-) \mathrm{fCH}$ & no \\
\hline \multirow{10}{*}{ L10 } & BA & $35 / 40-60 / 70$ & $2.5 \mathrm{YR} 4 / 6$ & $2.5 Y R 3 / 4$ & (2)3cSBK; (2)2-3f-mSBK; (4)2fGR & no & $(++) \mathrm{fCH}$ & no \\
\hline & $\mathrm{Bw}_{1}$ & $60 / 70-100 / 110$ & $2.5 Y R 4 / 8$ & $2.5 Y R 3 / 6$ & (1)2-1c-mSBK; (5)2-3fGR & $(+) f-v f D$ & $(++) \mathrm{fCH}$ & no \\
\hline & $\mathrm{Bw}_{2}$ & $100 / 110-180$ & $2.5 Y R 4 / 6$ & $2.5 \mathrm{YR} 3 / 6$ & (0)2cSBK, (3)1mSBK; (5)3f-vfGR & no & no & no \\
\hline & $\mathrm{Bw}_{3}$ & $180-210+$ & $2.5 \mathrm{YR} 4 / 8$ & $2.5 \mathrm{YR} 4 / 6$ & (2)2-1m-fSBK; (5)3f-vfGR & no & no & no \\
\hline & & & & & Red Latosol $^{(1)}-$ Rhodic Acrustox $^{(2)}-$ Rodhic Ferralsol $^{(3)}$ & & & \\
\hline & A & $0-15$ & $7.5 Y R 4 / 6$ & $2.5 \mathrm{YR} 2,5 / 4$ & (0)2cSBK; (4)3m-fSBK; (4)2fGR & $(++) \mathrm{fD}$ & $(+-) \mathrm{fCH}$ & no \\
\hline & $\mathrm{AB}$ & $15-40$ & $5 Y R 4 / 6$ & $2.5 \mathrm{YR} 3 / 4$ & (3)3cSBK; (3)3fSBK; (4)2-3fGR & $(++++) \mathrm{fD}$ & $(+) \mathrm{fCH}$ & no \\
\hline & $\mathrm{BA}$ & $40-70$ & $2.5 \mathrm{YR} 4 / 6$ & $2.5 Y R 3 / 4$ & (3)2-3cSBK; (3)3fSBK; (4)2-3fGR & $(+) f-v f D ;(++) f-m L C$ & $(+-) \mathrm{fCH}$ & no \\
\hline & $\mathrm{Bw}_{1}$ & $70-100$ & 5YR 5/6 & $2.5 \mathrm{YR} 3 / 6$ & (3)2mSBK; (4)3f-vfGR & $(+) \mathrm{vfD} ;(+-) \mathrm{vfLC}$ & no & no \\
\hline & $\mathrm{Bw}_{2}$ & $100-140$ & $2.5 Y R 4 / 6$ & $10 \mathrm{R} 4 / 8$ & (0)2-1c-mSBK and (2)2c-mGR and (5)3f-vfGR & no & no & no \\
\hline
\end{tabular}

Structure description: (frequency - grade - size - type).

Frequency: (0) rarely: < $1 \%$ of volume; (1) very little: 1 to $5 \%$ of volume; (2) little: 5 to $15 \%$ of volume; (3) common: 15 to $40 \%$ of volume; frequent (4): 40 to $80 \%$ of volume;

dominant (5): $>80 \%$ of volume. Grade: 1 - weak; 2 - moderate; 3 - strong. Size of granular structure: vf - very-fine $(<1-\mathrm{mm}) ; \mathrm{f}=\mathrm{fine}(1 \mathrm{to} 2-\mathrm{mm}) ; \mathrm{m}=\mathrm{medium}(2$ to 5 -mm);

$\mathrm{c}=$ coarse $(5$ to $10-\mathrm{mm}) ; \mathrm{vc}=$ very-coarse $(>10-\mathrm{mm})$. Size of subangular blocky: vf - very-fine $(<5-\mathrm{mm}) ; \mathrm{f}=$ fine $(5$ to $10-\mathrm{mm}) ; \mathrm{m}=\mathrm{medium}(10$ to $20-\mathrm{mm}) ; \mathrm{c}=\mathrm{coarse}$ (20 to 50-mm); vc = very-coarse (> 50-mm). Type: GR = granular; SBK = subangular blocky.

DIRV (Dense Irregular sub-Rounded Volumes) description: (frequency/grade - size - type). Frequency/grade: $(++++)=$ very strong; $(+++)=$ strong; $(++)=$ moderate; $(+)=$ weak; (+-) = very weak; no = not observed. Size of DIRV described as subangular blocky structure. Type: D = dispersed DIRV; LC $=$ locally concentrated DIRV.

Biological Activity description: (frequency/grade - size - type). Frequency/grade and size of biological activity described as DIRV. Type: $\mathrm{CH}=$ channels; $\mathrm{CV}=$ cavities.

Soil Type: (1) Brazilian Soil Taxonomy (Embrapa, 1999), (2) Soil Taxonomy (Soil Survey Staff, 2006), (3) World Reference Base (IUSS Working Group WRB, 2006). 
Table 3

Physical and chemical characteristics of the diagnostic horizons (Bw) of the Latosols (L) studied

\begin{tabular}{|c|c|c|c|c|c|c|c|c|c|c|c|c|c|c|c|c|c|c|c|}
\hline (L) & Hor. & $\begin{array}{l}<2 \mu \mathrm{m} \\
\left(\mathrm{g} \mathrm{kg}^{-1}\right)\end{array}$ & $\frac{2-50 \mu \mathrm{m}}{\left(\mathrm{g} \mathrm{kg}^{-1}\right)}$ & $\frac{50-2000 \mu \mathrm{m}}{\left(\mathrm{g} \mathrm{kg}^{-1}\right)}$ & $\frac{\mathrm{Db}}{\left(\mathrm{g} \mathrm{cm}^{-3}\right)}$ & $\frac{\mathrm{Dp}}{\left(\mathrm{g} \mathrm{cm}^{-3}\right)}$ & $\mathrm{pH}_{\mathrm{w}}$ & $\mathrm{pH}_{\mathrm{KCl}}$ & $\frac{\mathrm{OC}}{\left(\mathrm{g} \mathrm{kg}^{-1}\right)}$ & $\frac{\mathrm{Ca}^{2+}+\mathrm{Mg}^{2+}}{\left(\mathrm{cmol}_{\mathrm{c}} \mathrm{kg}^{-1}\right)}$ & $\frac{\mathrm{K}^{+}}{\left(\mathrm{cmol}_{\mathrm{c}} \mathrm{kg}^{-1}\right)}$ & $\frac{\mathrm{Na}^{+}}{\left(\mathrm{cmol}_{\mathrm{c}} \mathrm{kg}^{-1}\right)}$ & $\frac{\mathrm{Al}^{3+}}{\left(\mathrm{cmol}_{\mathrm{c}} \mathrm{kg}^{-1}\right)}$ & $\frac{\mathrm{H}^{+}+\mathrm{Al}^{3+}}{\left(\mathrm{cmol}_{\mathrm{c}} \mathrm{kg}^{-1}\right)}$ & $\frac{\mathrm{CEC}}{\left(\mathrm{cmol}_{\mathrm{c}} \mathrm{kg}^{-1}\right)}$ & $\frac{\mathrm{SiO}_{2}}{\left(\mathrm{~g} \mathrm{~kg}^{-1}\right)}$ & $\frac{\mathrm{Al}_{2} \mathrm{O}_{3}}{\left(\mathrm{~g} \mathrm{~kg}^{-1}\right)}$ & $\frac{\mathrm{Fe}_{2} \mathrm{O}_{3}}{\left(\mathrm{~g} \mathrm{~kg}^{-1}\right)}$ & $\frac{\mathrm{TiO}_{2}}{\left(\mathrm{~g} \mathrm{~kg}^{-1}\right)}$ \\
\hline L1 & $\mathrm{Bw}_{2}$ & 520 & 40 & 440 & 1.21 & 2.73 & 5.34 & 6.16 & 0.34 & 0.25 & 0.01 & 0.00 & 0.00 & 1.74 & 2.00 & 112 & 528 & 318 & 42 \\
\hline $\mathrm{L} 2$ & $\mathrm{Bw}_{2}$ & 610 & 140 & 250 & 0.90 & 2.76 & 5.30 & 6.20 & 0.61 & 0.16 & 0.00 & 0.00 & 0.00 & 10.44 & 10.60 & 187 & 565 & 225 & 23 \\
\hline L3 & $\mathrm{Bw}_{2}$ & 750 & 90 & 160 & 0.88 & 2.72 & 5.20 & 5.80 & 0.02 & 0.17 & 0.00 & 0.00 & 0.00 & 1.58 & 1.75 & 239 & 564 & 163 & 33 \\
\hline L4 & $\mathrm{Bw}_{1}$ & 300 & 10 & 690 & 1.18 & 2.64 & 5.24 & 5.73 & 0.34 & 0.24 & 0.01 & 0.00 & 0.00 & 1.48 & 1.73 & 123 & 651 & 213 & 13 \\
\hline L5 & $\mathrm{Bw}_{1}$ & 550 & 150 & 300 & 1.03 & 2.76 & 4.80 & 4.00 & 0.62 & 0.23 & 0.04 & 0.00 & 0.29 & 2.92 & 3.19 & 339 & 442 & 206 & 13 \\
\hline L6 & $\mathrm{Bw}_{2}$ & 780 & 90 & 130 & 0.83 & 2.65 & 4.80 & 5.50 & 0.02 & 0.18 & 0.01 & 0.00 & 0.00 & 9.80 & 9.99 & 250 & 502 & 227 & 21 \\
\hline L7 & $\mathrm{Bw}_{2}$ & 700 & 140 & 160 & 0.96 & 2.76 & 4.80 & 4.90 & 0.59 & 0.21 & 0.01 & 0.00 & 0.01 & 2.84 & 3.06 & 327 & 465 & 188 & 21 \\
\hline L8 & $\mathrm{Bw}_{2}$ & 760 & 70 & 170 & 0.98 & 2.88 & 4.90 & 4.20 & 0.61 & 0.20 & 0.01 & 0.00 & 0.18 & 8.84 & 9.05 & 331 & 448 & 203 & 18 \\
\hline L9 & $\mathrm{Bw}_{2}$ & 750 & 80 & 170 & 1.06 & 2.80 & 5.00 & 4.00 & 0.01 & 0.23 & 0.02 & 0.00 & 0.32 & 2.86 & 3.11 & 341 & 440 & 200 & 18 \\
\hline L10 & $\mathrm{Bw}_{2}$ & 750 & 70 & 180 & 0.88 & 2.76 & 5.20 & 4.30 & 0.02 & 0.91 & 0.02 & 0.00 & 0.09 & 4.66 & 5.59 & 226 & 514 & 239 & 22 \\
\hline
\end{tabular}

$\mathrm{Db}=$ bulk density, $\mathrm{Dp}$ = particle density, $\mathrm{OC}=$ Organic carbon, $\mathrm{CEC}$ = Cation exchange capacity. 
Table 4

Micromorphological analyses of the diagnostic horizons (Bw) of the Latosols (L) studied (description according to Bullock et al., 1985 and Stoops, 2003).

\begin{tabular}{|c|c|c|c|c|c|c|c|}
\hline \multirow[t]{2}{*}{ Latosol } & \multirow[t]{2}{*}{ Microstructure } & \multirow[t]{2}{*}{ Voids } & \multicolumn{3}{|c|}{$\begin{array}{l}\text { Groundmass } \\
\text { Fabric elements }\end{array}$} & \multicolumn{2}{|c|}{ Micromass } \\
\hline & & & $\begin{array}{l}\text { Distribution } \\
\text { patterns }\end{array}$ & $\begin{array}{c}\text { Orientation } \\
\text { patterns }\end{array}$ & $\begin{array}{l}\mathrm{c} / \mathrm{f}-\text { Related } \\
\text { Distribution }\end{array}$ & Color & b-fabric \\
\hline L1 & $\begin{array}{l}\text { highly separated and well developed pedality and granular microstructure }(50 \%) \\
\text { moderately separated and well developed pedality and granular microstructure }(35 \%) \\
\text { weakly separated and weakly developed pedality and massive microstructure }(15 \%)\end{array}$ & $\begin{array}{l}\text { compound packing voids } \\
\text { complex packing voids } \\
\text { regular and star-shaped vughs and planes } \\
\text { voids }\end{array}$ & random & unreferred & $\begin{array}{l}\text { double-spaced- } \\
\text { porphyric }\end{array}$ & $\begin{array}{l}\text { red to dark } \\
\text { red } \\
2.5 \text { YR } 4 / 8 \text { to } \\
\text { 10R } 3 / 5\end{array}$ & undifferentiated \\
\hline L2 & $\begin{array}{l}\text { highly separated and well developed granular microstructure }(70 \%) \\
\text { weakly separated and weakly developed pedality and massive microstructure (30\%) }\end{array}$ & $\begin{array}{l}\text { compound packing voids } \\
\text { regular and star-shaped vughs and planes } \\
\text { voids }\end{array}$ & random & unreferred & open-porphyric & $\begin{array}{l}\text { red } \\
2.5 \mathrm{YR} 4 / 8\end{array}$ & undifferentiated \\
\hline L3 & $\begin{array}{l}\text { highly separated and well developed pedality and granular microstructure (95\%) } \\
\text { weakly separated and weakly developed pedality and massive microstructure (5\%) }\end{array}$ & $\begin{array}{l}\text { compound packing voids and complex } \\
\text { packing voids }\end{array}$ & random & unreferred & open-porphyric & $\begin{array}{l}\text { brownish } \\
\text { yellow }\end{array}$ & undifferentiated \\
\hline L4 & $\begin{array}{l}\text { - highly to moderate separated and well developed pedality and granular microstructure and } \\
\text { pellicular grain microstructure }(100 \%)\end{array}$ & - simple to compound packing voids & random & unreferred & $\begin{array}{l}\text { chitonic to } \\
\text { (coarse-monic) }\end{array}$ & $\begin{array}{l}\text { yellow } \\
\text { 10YR } 7 / 8\end{array}$ & undifferentiated \\
\hline L5 & $\begin{array}{l}\text { highly to moderate separated and well developed pedality and microstructure }(60 \%) \\
\text { moderately separated and well developed pedality and granular microstructure }(20 \%) \\
\text { weakly separated and weakly developed pedality and massive microstructure }(20 \%)\end{array}$ & $\begin{array}{l}\text { compound packing voids } \\
\text { complex packing voids } \\
\text { channels and planes voids }\end{array}$ & random & unreferred & $\begin{array}{l}\text { open to } \\
\text { double-spaced- } \\
\text { porphyric }\end{array}$ & $\begin{array}{c}\text { dark red } \\
2.5 \mathrm{YR} 3 / 6\end{array}$ & undifferentiated \\
\hline L6 & $\begin{array}{l}\text { highly separated and well developed pedality and granular microstructure (95\%) } \\
\text { weakly separated and weakly developed pedality and massive microstructure (5\%) }\end{array}$ & - simple to compound packing voids & random & unreferred & open-porphyric & $\begin{array}{l}\text { dark red } \\
10 \mathrm{R} 3 / 6\end{array}$ & undifferentiated \\
\hline L7 & $\begin{array}{l}\text { highly separated and well developed pedality and granular microstructure }(65 \%) \\
\text { moderately separated and well developed pedality and granular microstructure (20\%) } \\
\text { weakly separated and weakly developed pedality and massive microstructure (15\%) }\end{array}$ & $\begin{array}{l}\text { compound packing voids } \\
\text { complex packing voids } \\
\text { regular and star-shaped vughs and planes } \\
\text { voids }\end{array}$ & random & unreferred & open-porphyric & $\begin{array}{c}\text { red } \\
2.5 \mathrm{YR} 4 / 8\end{array}$ & undifferentiated \\
\hline L8 & $\begin{array}{l}\text { highly separated and well developed pedality and granular microstructure }(60 \%) \\
\text { moderately separated and well developed pedality and granular microstructure }(30 \%) \\
\text { weakly separated and weakly developed pedality and massive microstructure }(10 \%)\end{array}$ & $\begin{array}{l}\text { compound packing voids } \\
\text { complex packing voids } \\
\text { regular and star-shaped vughs and planes } \\
\text { voids }\end{array}$ & random & unreferred & open-porphyric & $\begin{array}{l}\text { dark red to } \\
\text { red } 10 \mathrm{R} 3 / 6 \\
\text { to } 4 / 8\end{array}$ & undifferentiated \\
\hline L9 & $\begin{array}{l}\text { highly separated and well developed pedality and granular microstructure }(55 \%) \\
\text { moderately separated and well developed pedality and granular microstructure (30\%) } \\
\text { weakly separated and weakly developed pedality and massive microstructure (15\%) }\end{array}$ & $\begin{array}{l}\text { compound packing voids } \\
\text { complex packing voids } \\
\text { regular and star-shaped vughs and planes } \\
\text { voids }\end{array}$ & random & unreferred & open-porphyric & $\begin{array}{c}\text { red } \\
2.5 \mathrm{YR} 4 / 8\end{array}$ & undifferentiated \\
\hline L10 & $\begin{array}{l}\text { highly separated and well developed pedality and granular microstructure }(75 \%) \\
\text { moderately separated and well developed pedality and granular microstructure }(20 \%) \\
\text { weakly separated and weakly developed pedality and massive microstructure }(5 \%)\end{array}$ & $\begin{array}{l}\text { compound packing voids } \\
\text { complex packing voids }\end{array}$ & random & unreferred & open-porphyric & $\begin{array}{l}\text { red } \\
2.5 \text { YR } 4 / 8\end{array}$ & undifferentiated \\
\hline
\end{tabular}

c/f: course/fine material in the groundmass 
Table 5

Mineralogy of the diagnostic horizons $(\mathrm{Bw})$ of the Latosols (L) studied

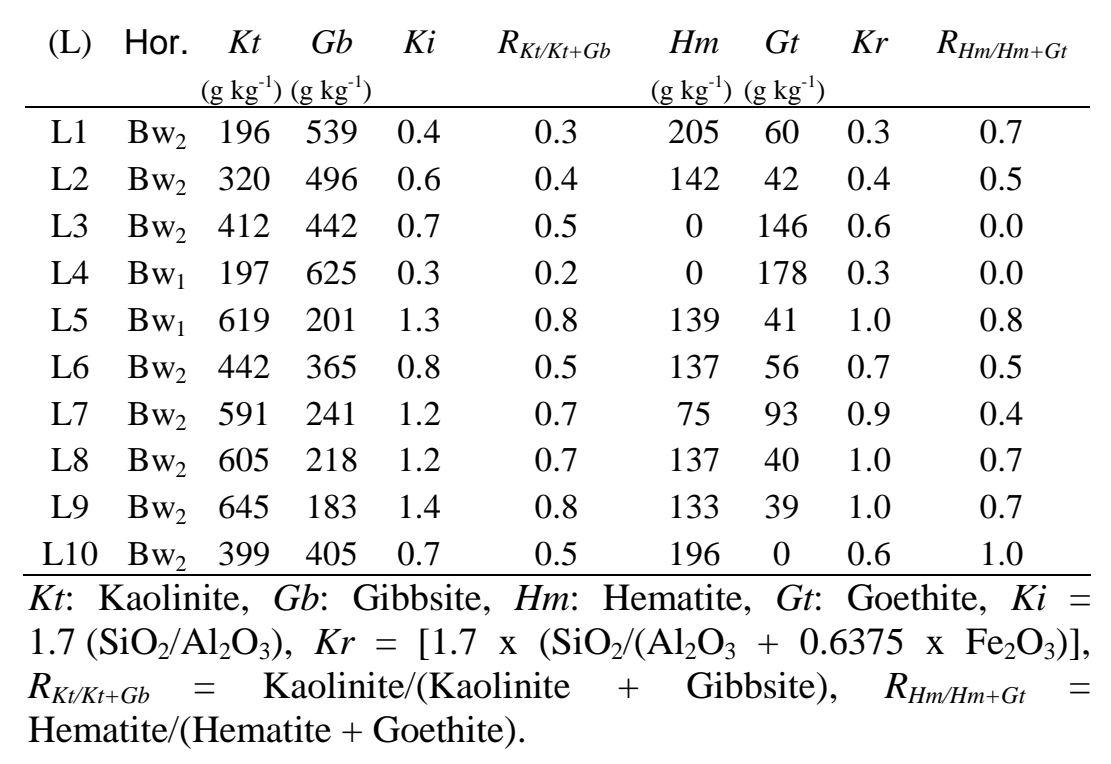


Table 6

Volume of voids resulting from the assemblage of the microaggregates (inter-aggregates voids) for the Bw horizons of the Latosols (L) studied

\begin{tabular}{lc}
\hline Latosol & $\begin{array}{c}\text { Volume of inter-microaggregates voids }\left(V_{v}^{\text {inter }}\right) \\
\left(\mathrm{cm}^{3} \mathrm{~g}^{-1}\right)\end{array}$ \\
\hline L1 & 0.305 \\
L2 & 0.556 \\
L3 & 0.547 \\
L4 & 0.375 \\
L5 & 0.453 \\
L6 & 0.585 \\
L7 & 0.472 \\
L8 & 0.439 \\
L9 & 0.359 \\
L10 & 0.540 \\
\hline
\end{tabular}

